\title{
EVALUATION OF DIFFERENT MODELS FOR THE ORIGIN OF THE SIBERIAN
}

\section{TRAPS}

Ivanov A.V.

Institute of the Earth’s Crust, Siberian Branch, Russian Academy of Sciences

\section{Abstract}

Various evidence, including size and volume of the Siberian Traps, timing and duration of eruptions, paleotectonic and paleogeographic reconstructions, lithospheric structure, heat flow, trace element and radiogenic isotope compositions of lava are reviewed in this chapter. The major evidence may be summarized as follows. The Siberian Traps erupted in a number of brief volcanic events from the Late Permian until the end of the Middle Triassic. They occupied a vast region (about $7 \times 10^{6} \mathrm{~km}^{2}$ ) in a back-arc tectonic setting. The overall volume of erupted rocks was as much as $\sim 4 \times 10^{6} \mathrm{~km}^{3}$ with most of the volume erupted within the Tunguska syncline. This syncline experienced long-term subsidence before initiation of the volcanism and the region is now underlain by thinnest lithosphere, which is about $180 \mathrm{~km}$ thick. Two types of trace element patterns are observed in the Siberian Traps; subordinate high-Ti ocean-island-basalt-like patterns, and dominant low-Ti island-arc-basalt-like patterns. In radiogenic isotope and trace element coordinates, mixing trends between these two types of magma are absent or, at least, not evident. Some volcanic rocks contain primary magmatic mica. These are considered in light of different models. Each model can explain, or was thought to explain, particular observations. However, some evidence can be fatal for some models. For example, the enormous size and volume cannot be explained in the framework of impact and edge-driven convection models, and is problematic for lithospheric delamination models. Plume models face problems explaining the uplift/subsidence pattern and the absence of mixing curves between expected high-Ti primary plume melts and contaminated low-Ti melts. Therefore a model which relates Siberian Trap magmatism and subduction is suggested. In this model, subducting slabs brought significant amounts of water into the mantle transition zone. Consequent release of water from the transition zone lowered the solidus of the upper mantle, leading to voluminous melting. Major supporting observations for this model include: (1) the tectonic position of the Siberian Traps in a back-arc setting of Permian subduction systems, (2) island-arc-basalt-like trace element patterns for the majority of the erupted basalts, (3) primary mica found in volcanic rocks and (4) experimental data on 
the high water capacity of the mantle transition zone and its recharging via the subduction process.

Keywords: Siberian Traps, subduction, plume, delamination, convection, impact

\section{INTRODUCTION}

A number of completely different models have been discussed in the scientific literature to explain the origin of the Siberian Traps. These include the extraterrestrial bolide impact model (Jones et al., 2002) and terrestrial models, which consider the Siberian Traps either to result from a large mantle plume from the core-mantle boundary (Campbell and Griffiths, 1990), lithospheric delamination involving a weaker plume (Elkins-Tanton, 2005), redistribution of heat in the upper mantle without a plume (King and Anderson, 1998; Puffer, 2001), or saturation of the upper mantle with water following prolonged subduction beneath Siberia (Ivanov and Balyshev, 2005). The plume model is the most popular and thus it is considered the conventional model. Other models are viewed as alternatives. Each model employs its own line of arguments. Useful evidence includes the magma volumes, timing of magmatism, uplift history, geophysical data, trace element and isotope geochemistry. This chapter evaluates the conventional and alternative models from the viewpoint of the evidence.

\section{TERMINOLOGY}

\section{Large Igneous Province and Flood Basalt Province}

The Siberian traps contain mafic, ultramafic, and silicic rocks, both intrusive and effusive. In this sense the Siberian Traps is a Large Igneous Province (LIP) because it is large and igneous (for discussion of the definition and classification of LIPs see http://www.mantleplumes.org/LIPClass.html\#Discussion). The Siberian Traps were built from one or more volcanic events involving the outpouring of large volumes of mainly basaltic magma. The large volumes distinguish the Siberian Traps which are, in this sense, a flood basalt province (FBP). Therefore, in this chapter I use two terms; (1) the Siberian Traps LIP, meaning the spatially and temporally related rocks of different composition and probably variable origin and (2) the Siberian traps FBP, meaning the large volume of mainly basaltic volcanic units. The majority of the Siberian traps FBP have distinct subduction-like major and 
trace element features such as low concentrations of high-field-strength elements (HFSE) relative to large ion lithophile elements (LILE) (Fedorenko et al., 1996; Puffer, 2001; Ivanov and Balyshev, 2005).

\section{Plumes and plate tectonic processes}

Morgan (1971) suggested that plumes are localized upwelling convective currents originating in the lower mantle, probably at the core-mantle boundary. He suggested plumes are the driving force for plate tectonics. As noted by Korenaga (2005), in the fluid dynamic literature a plume is any self-buoyancy driven flow. In this sense, all subducting slabs, sinking delaminated lower crust and Morganian lower-mantle upwellings are plumes. Such a usage of the term is, however, unacceptable to Earth scientists, who distinguish between subductionrelated volcanism occurring at plate boundaries, and intraplate volcanism occurring far from plate boundaries. Many different, sometimes contradictory, definitions of plumes can be found in the literature. A complete survey of plume definitions is beyond the scope of this chapter, but the following is from Campbell (2005), which expresses a commonly held view of what a "mantle plume" is:

High-pressure experimental studies of the melting point of iron-nickel alloys show that the core is several hundred degrees hotter than the overlying mantle. A temperature difference of this magnitude is expected to produce an unstable boundary layer above the core which, in turn, should produce plumes of hot, solid material that rise through the mantle, driven by their thermal buoyancy. Therefore, from theoretical considerations, mantle plumes are the inevitable consequence of a hot core.

Such plumes, referred to as Morganian by Courtillot et al. (2003), are often viewed as a phenomenon unrelated to plate tectonics. Plates can be driven by cooling from above without internal heating (Anderson, 2001), whereas Morganian plumes are driven by heating from the core (Courtillot et al., 2003; Campbell, 2005). According to the conventional view, Morganian plumes are necessary to form LIPs. They may or may not lead to break-up of a continent (e.g. the Central Atlantic Magmatic Province and Siberian Traps, respectively). Therefore, in evaluating plume model in this chapter, I use the term plume only for first order upwelling currents, which are either unrelated to plate tectonics or play a role of its driving force. Any upper-mantle processes (e.g. shallow recycling of subducted material, upper mantle convection) are considered to be non-plume, plate tectonic processes. Lithospheric 
delamination may be related either to plume or plate tectonic processes depending on the original causes of the delamination.

\section{EVIDENCE}

\section{Size and volume}

The Siberian Traps LIP is one of the largest in size and volume on the Earth, though estimates vary significantly. For example, Fedorenko et al. (1996) referred to the work of Milanovskiy (1976), whose estimates were $\sim 4 \times 10^{6} \mathrm{~km}^{2}$ and $>2 \times 10^{6} \mathrm{~km}^{3}$ for size and volume. Fedorenko et al. (1996) wrote 'We believe that even this volume may be underestimated ...'. Reichow et al. (2002) estimated separately the sizes for the Siberian Traps LIP located on the Siberian Craton and in the West Siberian Basin as $2.6 \times 10^{6} \mathrm{~km}^{2}\left(1 \times 10^{6} \mathrm{~km}^{3}\right)$ and $1.3 \times 10^{6} \mathrm{~km}^{2}$ $\left(1.3 \times 10^{6} \mathrm{~km}^{3}\right)$, respectively. The distribution of igneous rocks which can be attributed to the Siberian Traps LIP, is shown in Fig. 1 (Masaitis, 1983). According to this author the area of the Siberian Traps LIP is about $7 \times 10^{6} \mathrm{~km}^{2}$ and the volume could be as much as $4 \times 10^{6} \mathrm{~km}^{3}$. This volume is not the largest reported in the literature. Dobretsov (2003) estimated over $16 \times 10^{6} \mathrm{~km}^{3}$ including the Kara and Barents undersea areas.

Various estimates reported in the literature are summarized in Table 1. Most of these, however, are rough guesses from the size and average thickness of volcanogenic deposits. Precise calculation of the volume has been performed only by Vasil'ev et al. (2000). These authors focused on the cratonic part and calculated separately the present-day preserved volume of lava, volcanoclastic and intrusive rocks using geological survey data. Note that the size of the Siberian Traps erupted on the platform after Vasil'ev et al. (2000) is of the same order as the size assumed by Milanovskiy (1976) and Reichow et al. (2002) for the whole LIP. This in part is because a large part of the Siberian platform experienced only intrusive magmatism with extensive but relatively low-volume sills, which are hardly exposed on the surface and known mostly from drilling. The volume estimated by Vasil'ev et al. (2000) is $1.752 \times 10^{6} \mathrm{~km}^{3}$ over half of which is located in the Tunguska syncline. Tuffs are abundant within the syncline (Fig. 1). 


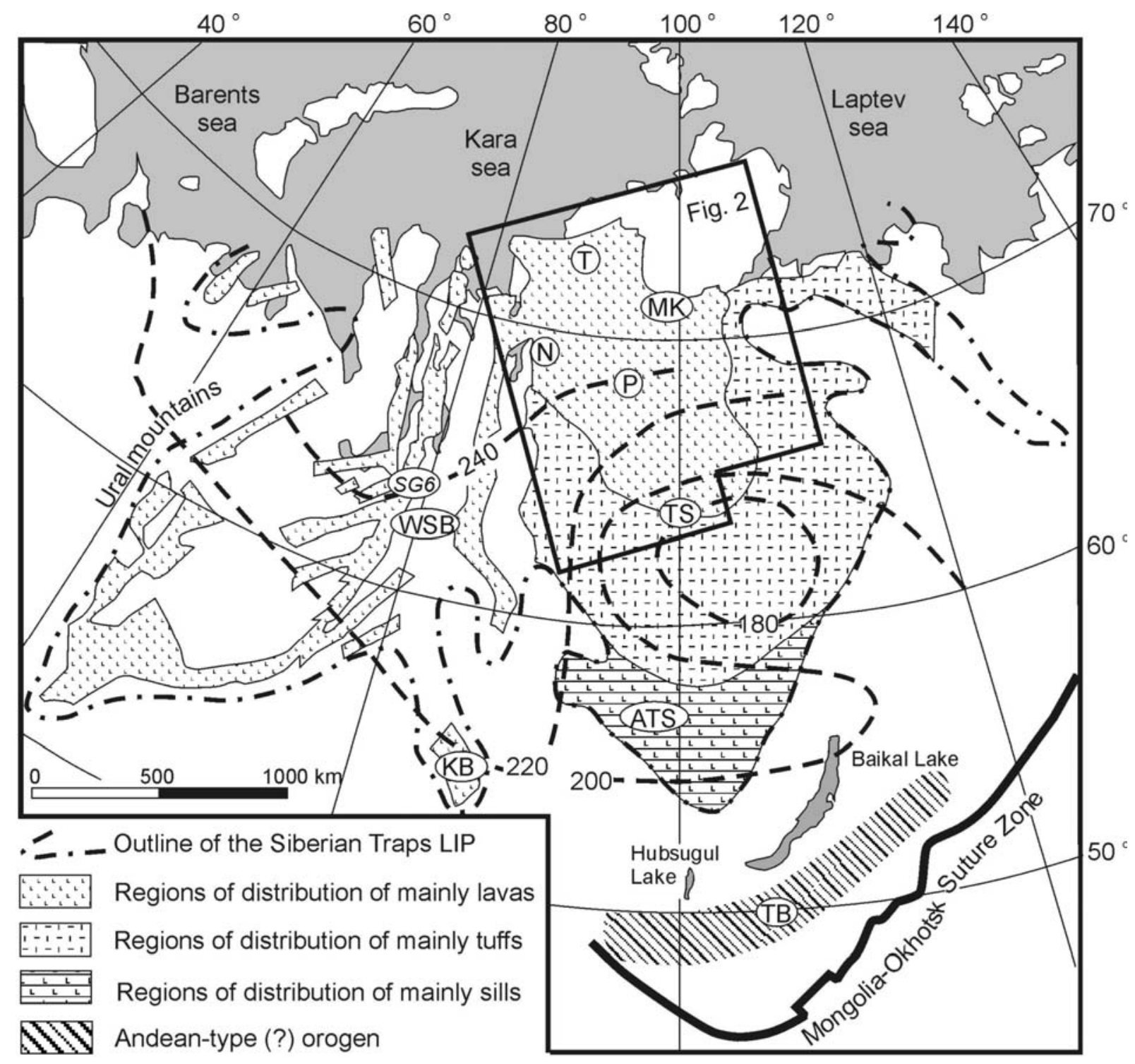

Fig. 1. The Siberian Traps LIP (simplified and modified after Masaitis, 1983). Position of the Mongolia-Okhotsk Suture Zone and Permo-Triassic volcano-plutonic complexes of Mongolia and Transbaikalia (Russia) are shown after Zorin (1999) and Yarmolyuk et al. (2001), respectively. Bold dashed lines with numbers represent depths in $\mathrm{km}$ of the L-boundary, detected by nuclear explosion seismic data, which probably marks the lithosphereasthenosphere boundary (Pavlenkova and Pavlenkova, 2006). WSB - West Siberian Basin, N - Noril'sk, MK - Maimecha-Kotui, P - Putorana, T - Taymyr, TS - Tunguska Syncline, ATS - Angara-Taseevskaya Syncline, KB - Kuznetsk Basin, TB - Transbaikalian Belt, DA Daldyn-Alakit field of pre-traps kimberlites. SG6 - Super deep drill-hole 6. Rectangle shows the location of the area shown in Fig. 2.

The estimates discussed above form three general groups; (1) a size of about $4 \times 10^{6}$ $\mathrm{km}^{2}$ and a volume of about $2 \times 10^{6} \mathrm{~km}^{3}$ (Milanovskiy, 1976; Reichow et al., 2002), (2) a size of about $7 \times 10^{6} \mathrm{~km}^{2}$ and a volume of about $4 \times 10^{6} \mathrm{~km}^{3}$ (Masaitis, 1983; Vasil'ev et al., 2000) and (3) a size of over $1 \times 10^{7} \mathrm{~km}^{2}$ and a volume of $1.6 \times 10^{7} \mathrm{~km}^{3}$ (Dobretsov, 2003). In my view, the 
first group underestimates by a factor of about two, whereas the third group may be an overestimation. A volume of the order of $\mathbf{4} \times \mathbf{1 0}^{\mathbf{6}} \mathbf{~} \mathbf{m}^{3}$ is probably close to the true value. It is worth mentioning that this includes various types of rocks from ultrabasic to acidic with basalts as the major rock type. Ultrabasic magmas (meimechites) erupted in large volumes in the Meimecha-Kotui region. Rhyolites and dacites are found in subordinate amounts in the West Siberian Basin (Masaitis, 1983; Medvedev et al., 2003). The volume of the Siberian Traps FBP is hard to estimate precisely, since it requires additional constraints from timing. However, it should be only slightly below the total LIP value.

Table 1. Estimates of the size and volume of the Siberian Traps LIP.

\begin{tabular}{lll}
\hline Papers (in chronological order) & Size $\left(10^{6} \mathrm{~km}^{2}\right)$ & Volume $\left(10^{6} \mathrm{~km}^{3}\right)$ \\
\hline Milanovskiy, 1976 & $\sim 4$ & $\geq 2$ \\
Masaitis, 1983 & $\sim 7 \times 10^{6}$ & $\leq 4$ \\
Fedorenko et al., 1996 & n.r. & $>2$ \\
Vasil'ev et al., $2000^{\xi}$ & $4.3^{\xi} \times 2 \sim 8.6$ & $1.75^{\xi \phi} \times 2 \sim 3.5$ \\
Reichow et al., 2002 & 3.9 & 2.3 \\
Dobretsov, 2003 & n.r. & $\geq 16$ \\
\hline
\end{tabular}

n.r. - not reported, ${ }^{\xi}$ - the calculations of Vasil'ev et al. (2000) were only for the Siberian Craton so they multiplied by 2 to estimate the total, ${ }^{\phi}-$ the present-day preserved value.

\section{Timing}

Comments on the use of different isotopic systems

The question of timing is discussed here on the basis of U-Pb and ${ }^{40} \mathrm{Ar} /{ }^{39} \mathrm{Ar}$ dating. Both radioisotopic systems may give erroneous ages due to loss of radiogenic lead and argon (giving younger apparent ages) and inherited lead and extraneous argon (giving older apparent ages). In general, particular criteria such as concordance in the U-Pb system and plateaus in the ${ }^{40} \mathrm{Ar} /{ }^{39} \mathrm{Ar}$ system have been developed to separate the true crystallization ages from apparent ages. However, when dealing with a short time duration, an error of a few million years may bias the conclusions (e.g. see Renne (1995) for ${ }^{40} \mathrm{Ar} /{ }^{39} \mathrm{Ar}$ reconsideration of the Noril'sk-I intrusion and Mundil et al. (2004) for debate on the U-Pb age of the PermoTriassic boundary). Zircon and baddeleyite U-Pb ages are usually considered more reliable than ${ }^{40} \mathrm{Ar} /{ }^{39} \mathrm{Ar}$ ages. However, zircon and baddeleyite are rare minerals in basaltic melts and thus there are few published U-Pb ages for the Siberian Traps FBP. ${ }^{40} \mathrm{Ar} /{ }^{39} \mathrm{Ar}$ ages are more abundant. They are reported (recalculated) here relative the same age of $98.79 \mathrm{Ma}$ for the 
GA1550 standard (Renne et al., 1998) unless otherwise is stated. The choice of this age merely reflects the fact that it is used in two most recent reviews for the Siberian Traps (Reichow et al., 2002; Ivanov et al., 2005). Accepting this age for the GA1550 standard makes ${ }^{40} \mathrm{Ar} /{ }^{39} \mathrm{Ar}$ ages $\sim 0.7 \%$ younger than U-Pb ages. The reason for the difference is most likely due to biased ${ }^{40} \mathrm{~K}$ decay constants (e.g. Ivanov, 2006; Min et al., 2000) Using a more recent value of $98.5 \mathrm{Ma}$ (Spell and McDougall, 2003) for the GA1550 standard makes the ${ }^{40} \mathrm{Ar} /{ }^{39} \mathrm{Ar}$ ages $~ 0.9 \%$ younger than U-Pb ages (Ivanov, 2006). The errors of ${ }^{40} \mathrm{Ar} /{ }^{39} \mathrm{Ar}$ ages shown here are at the $2 \sigma$ level including reported analytical errors on the J-factor, but not including errors which would result from inhomogeneities of the standards (because this information is rarely reported in original publications) and errors of intercalibration of the standards.

\section{Duration of Siberian Traps FBP magmatism}

A short duration for Siberian Traps FBP magmatism was suggested on the basis of two ${ }^{40} \mathrm{Ar} /{ }^{39} \mathrm{Ar}$ ages (Renne and Basu, 1991) for the stratigraphically oldest and youngest lava units in the northern part of the FBP (for location of dated samples see Fig. 2). Later it was shown that these ages are statistically indistinguishable from the ${ }^{40} \mathrm{Ar} /{ }^{39} \mathrm{Ar}$ age for the Permo-Triassic boundary dated at the Meishan section in China (Renne et al., 1995). Since then, the Siberian Traps FBP has been widely considered to have formed during 1 Ma or less despite older and younger ages having been published (e.g. Dalrymple et al., 1995; Reichow et al., 2002). For example, Walderhaug et al. (2005) obtained Middle-Late Triassic ${ }^{40} \mathrm{Ar} /{ }^{39} \mathrm{Ar}$ ages and paleomagnetic poles for dolerite sills emplaced within Taimyr Peninsula and concluded that these rocks are unrelated to Siberian Traps FBP because of the assumption that the Siberian Traps FBP was a Permo-Triassic boundary event. However, to be correct, it is unknown when there were major (by volume) events within the Siberian Traps. Fig. 2 summarizes dated localities within about $1 / 4$ of the Siberian Traps LIP. It clearly shows that most PermoTriassic ages come from a narrow strip from the Noril'sk-Kharaelkah to the Maimecha-Kotui subprovince. Huge regions have not been studied by precise radioisotopic age dating!

A basis for suggesting that the Siberian Traps FBP formed over a prolonged interval of time up to the Middle-Late Triassic, and probably in multiple volcanic events, is the following: (a) Tunguska subprovince, with the most voluminous volcanic deposits (see estimations of the volume above) is characterized by Middle Triassic and Middle-Late Triassic ${ }^{40} \mathrm{Ar} /{ }^{39} \mathrm{Ar}$ ages $(240.7 \pm 2.8 \mathrm{Ma}$ for Korvuchana tuffs and $232.1 \pm 4.6$ Ma for an 
uppermost lava unit; Baksi and Farrar, 1991), (b) Usol'skii sill emplaced within AngaraTaseevskaya Syncline (Fig. 1) yielded an Early Triassic ${ }^{40} \mathrm{Ar} /{ }^{39} \mathrm{Ar}$ age (243.9 $\pm 1.4 \mathrm{Ma}$; Ivanov et al., 2005), (c) combined paleomagnetic and ${ }^{40} \mathrm{Ar} /{ }^{39} \mathrm{Ar}$ studies show that doleritic sills at Taimyr peninsula were emplaced in the Middle-Late Triassic $(230.2 \pm 14,230.7 \pm 2.5$, $232.5 \pm 8 \mathrm{Ma}$; Walderhaug et al., 2005), (d) Daldykan dolerite sill emplaced within the Noril'sk-Kharaelakh subprovince and Avamsky dike within the Kamensk subprovince yielded Middle and Middle-Late Triassic ${ }^{40} \mathrm{Ar} /{ }^{39} \mathrm{Ar}$ ages respectively (229.9 \pm 2.6 and $226.4 \pm$ 1.6 Ma; Dalrymple et al., 1995), (e) lamproite dikes in the southern mountains framing the Kuznetsk Basin yielded Early and Middle Triassic ${ }^{40} \mathrm{Ar} /{ }^{39} \mathrm{Ar}$ ages (the original ${ }^{40} \mathrm{Ar} /{ }^{39} \mathrm{Ar}$ values relative to the MCA-11 standard with no reported age were $244.0 \pm 0.8,244.4 \pm 0.8$, $245.7 \pm 0.7$ and $236.5 \pm 3.8 \mathrm{Ma}$; Vrublevskii et al., 2004), (f) the Nadezhdinsky and HonaMakitsky suites within the Central-Putorana subprovince yielded ${ }^{40} \mathrm{Ar} /{ }^{39} \mathrm{Ar}$ ages of $246.6 \pm$ 2.4 and $241.0 \pm 2.5$ Ma, respectively (the absolute values may be slightly biased by the Jfactor, but the age difference of 5.6 \pm 3.5 Ma will remain unchanged for these two suites as discussed by Ivanov et al. (2006), (g) combined paleomagnetic and biostratigraphic study of the SG-6 superdeep drill-hole revealed that volcanic rocks in the deep rift structures of the West Siberian Basin were formed up to the Early-Middle Triassic (Olenekian-Anisian) (Kazanskii et al., 2000).

Many of the above-mentioned volcanic and intrusive rocks have been traditionally considered to be part of the Siberian Traps FBP. In the section on geochemistry I shall show that Usol'skii sill dolerites are practically indistinguishable on the basis of trace elements from geochemically uniform upper lava units in the Noril'sk-Kharaelakh subprovince. Therefore, similar composition magmas were erupted in different regions at different times. A detailed ${ }^{40} \mathrm{Ar} /{ }^{39} \mathrm{Ar}$ study of the Ethiopian traps FBP revealed the same feature; chemically similar magmas erupted during different pulses of volcanism (Kieffer et al., 2004).

It is worth repeating that thick lavas in the north Siberian Traps were formed briefly at the Permo-Triassic boundary, but in other regions voluminous eruptions occurred during other, probably also brief, periods of time (Fig. 3).

\section{Timing of initial eruptions within the Siberian Traps FBP}

Basu et al. (1995) reported the Late Permian ${ }^{40} \mathrm{Ar} /{ }^{39} \mathrm{Ar}$ age of $253.3 \pm 2.6$ Ma for phlogopite from olivine nephelinite in the Arydjansky suite, which represents the initial phase 
of magmatism in the north of the Maimecha-Kotui subprovince. This age is significantly older than the Permo-Triassic age of the initial lava suites at Khantaisk-Rybninsk subprovince dated in the same laboratory (Renne and Basu, 1991). However, Kamo et al. (2003) reported the U$\mathrm{Pb}$ perovskite age of $251.7 \pm 0.4 \mathrm{Ma}$ for the Arydjansky suite, which is indistinguishable from the Permo-Triassic U-Pb zircon and baddeleyite age $251.2 \pm 0.3$ Ma for the Noril’sk-I orebearing intrusion at Noril'sk-Kharaelakh subprovince (Kamo et al., 1996).

Ivanov (2006) compared ${ }^{40} \mathrm{Ar} /{ }^{39} \mathrm{Ar}$ and U-Pb ages obtained for the same intrusions and lava units from the Siberian Traps LIP among other regions and showed that ${ }^{40} \mathrm{Ar} /{ }^{39} \mathrm{Ar}$ ages are systematically younger than U-Pb ages. The exception is the ${ }^{40} \mathrm{Ar} /{ }^{39} \mathrm{Ar}-\mathrm{U}-\mathrm{Pb}$ pair age for the Arydjansky suite. This inconsistency may be explained by either excess argon in the phlogopite, which leads to an older apparent ${ }^{40} \mathrm{Ar} /{ }^{39} \mathrm{Ar}$ age or an incorrect correction for the initial $\mathrm{Pb}$ composition in the perovskite, which would lead to a younger U-Pb age.

Reichow et al. (2002) obtained Late Permian ${ }^{40} \mathrm{Ar} /{ }^{39} \mathrm{Ar}$ ages for biotites from olivine gabbros of the Van Eganskaya borehole within the West Siberian Basin (253.4 \pm 0.8 and $252.5 \pm 1.5 \mathrm{Ma}$ ). These ages and $\mathrm{a}{ }^{40} \mathrm{Ar} /{ }^{39} \mathrm{Ar}$ age for the Arydjansky suite are statistically indistinguishable. To verify this, Ivanov et al. (2006) performed a Monte-Carlo test as follows. First, it was assumed that all Permo-Triassic ${ }^{40} \mathrm{Ar} /{ }^{39} \mathrm{Ar}$ ages are true crystallization ages. Second, a dataset of ages in the range 260 to 220 Ma with errors similar to true analytical errors was stochastically created. Third, the Permo-Triassic and stochastic ages were plotted as probability distribution. The second and third steps were repeated about 100 times. The highest stochastic peak heights are lower than that of late Permian ${ }^{40} \mathrm{Ar} /{ }^{39} \mathrm{Ar}$ peak showing that coincidence between West Siberian Basin gabbro and Arydjansky suite ages are not due to stochastic errors (Fig. 3).

In the Kuznetsk Basin there are mafic rocks of both Late Permian and Early Triassic age (e.g. Dobretsov et al., 2005). Reported ${ }^{40} \mathrm{Ar} /{ }^{39} \mathrm{Ar}$ ages (Dobretsov et al., 2005) are, however, not supported by analytical details, whereas all age spectra shown by Fedoseev et al. (2005) revealed disturbed K-Ar isotope systems in the samples studied (though the authors, being unaware of it, interpreted the spectra as true crystallization ages). Paleomagnetic study of the SG-6 superdeep drill-hole has shown that the initial volcanic rocks are as old as latest Late Permian (upper part of the Late Tatatrian) (Kazanskii et al., 2000). 


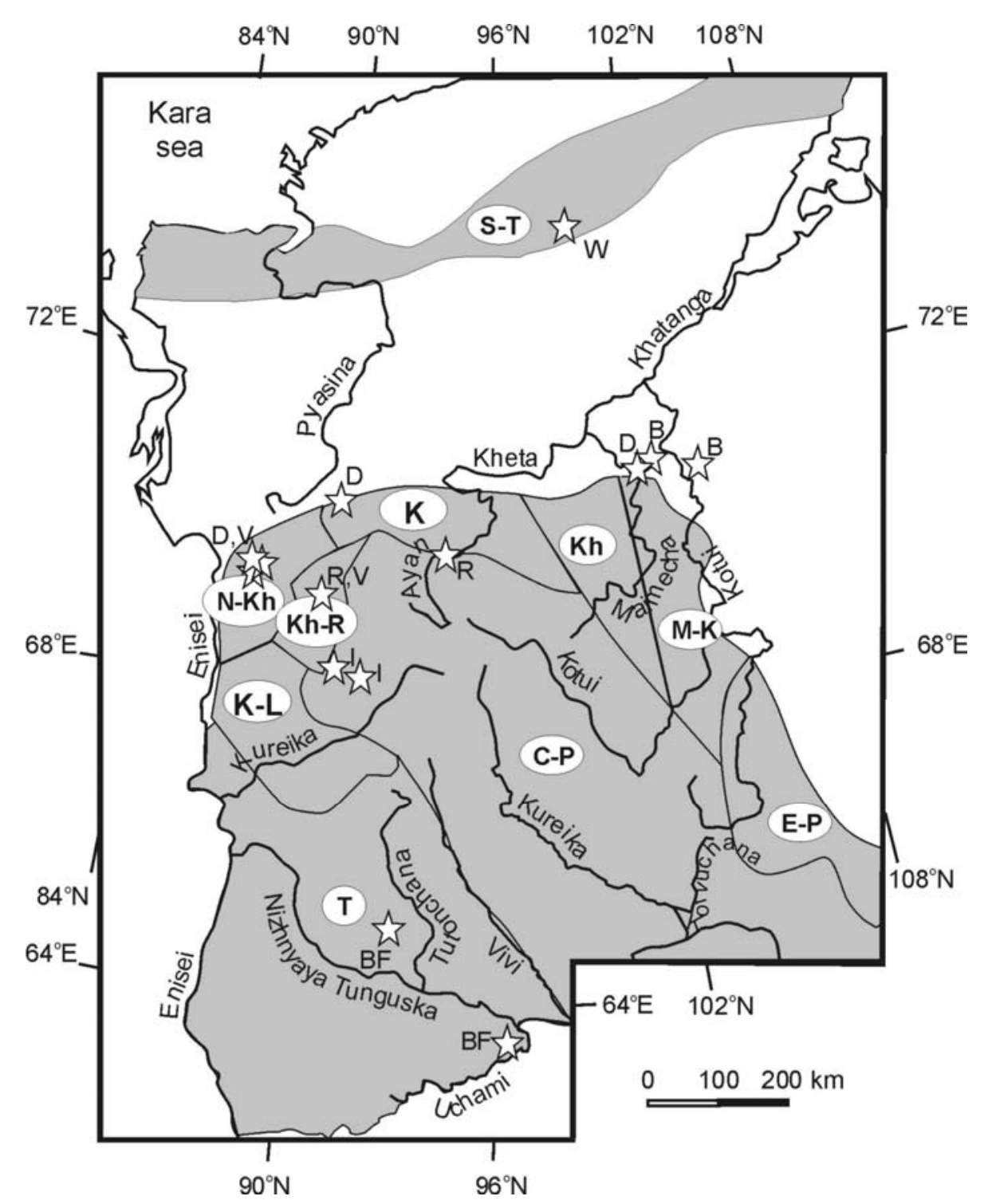

Fig. 2. Volcanic sub-provinces of the central and northern part of the Siberian Traps LIP (after Zolotuhin et al., 1984). N-Kh - Noril'sk-Kharaelakh, Kh-R - Khantaisk-Rybninsk; K Kamensk; Kh - Kheta; M-K - Maimecha-Kotui; K-L - Kureika-Letninsk; C-P - Central Putorana; E-P - Eastern Putorana; T - Tunguska; S-T - South Taimyr. Stars mark localities of ${ }^{40} \mathrm{Ar} /{ }^{39} \mathrm{Ar}$ dated samples: BF - Baksi and Farrar (1991); R - Renne and Basu (1991); D Dalrymple et al. (1995); Basu et al. (1995); Venkatesan et al. (1997); W - Walderhaug et al. (2005); I - Ivanov et al. (2006). U-Pb dated samples are located in the Noril'sk-Kharaelakh and Maimecha-Kotui subprovinces, practically at the same places marked 'D' and ' $B$ ' (Kamo et al., 1996; 2003). One sample dated by Renne and Basu (1991) was taken from a submeridian part of the Ayan river near the junction of the C-P and K sub-provinces, not in the central part of the C-P as shown in Renne and Basu (1991). Localities for samples marked 'BF' are restored from regions studied by Dmitriev (1973), who donated the samples for the ${ }^{40} \mathrm{Ar} /{ }^{39} \mathrm{Ar}$ study of Baksi and Farrar (1991), and may be not absolutely precise. Volcanic rocks between South-Taimyr and Noril'sk-Kharaelakh, Kamensk, and Kheta sub-provinces and to the west of the river Enisei are covered by Mesozoic and Cenozoic sediments. The area south to the river Uchami was not studied at the same level in the 1980s and therefore is not marked as a separate sub-province. Each sub-province is characterized by its own stratigraphical units, which were correlated with each other on the basis of petrography and chemistry. 
Summarizing the data presented in this section it should be mentioned that the question of timing of the initial eruptions within the Siberian Traps FBP requires further geochronological investigation. At present, it is obvious that in the West Siberian Basin the oldest mafic magmas erupted at the end of the Permian. Probably, simultaneous eruptions of mafic magmas took place in the Kuznetsk Basin and in the north of the Siberian Craton (Maimecha-Kotui subprovince).

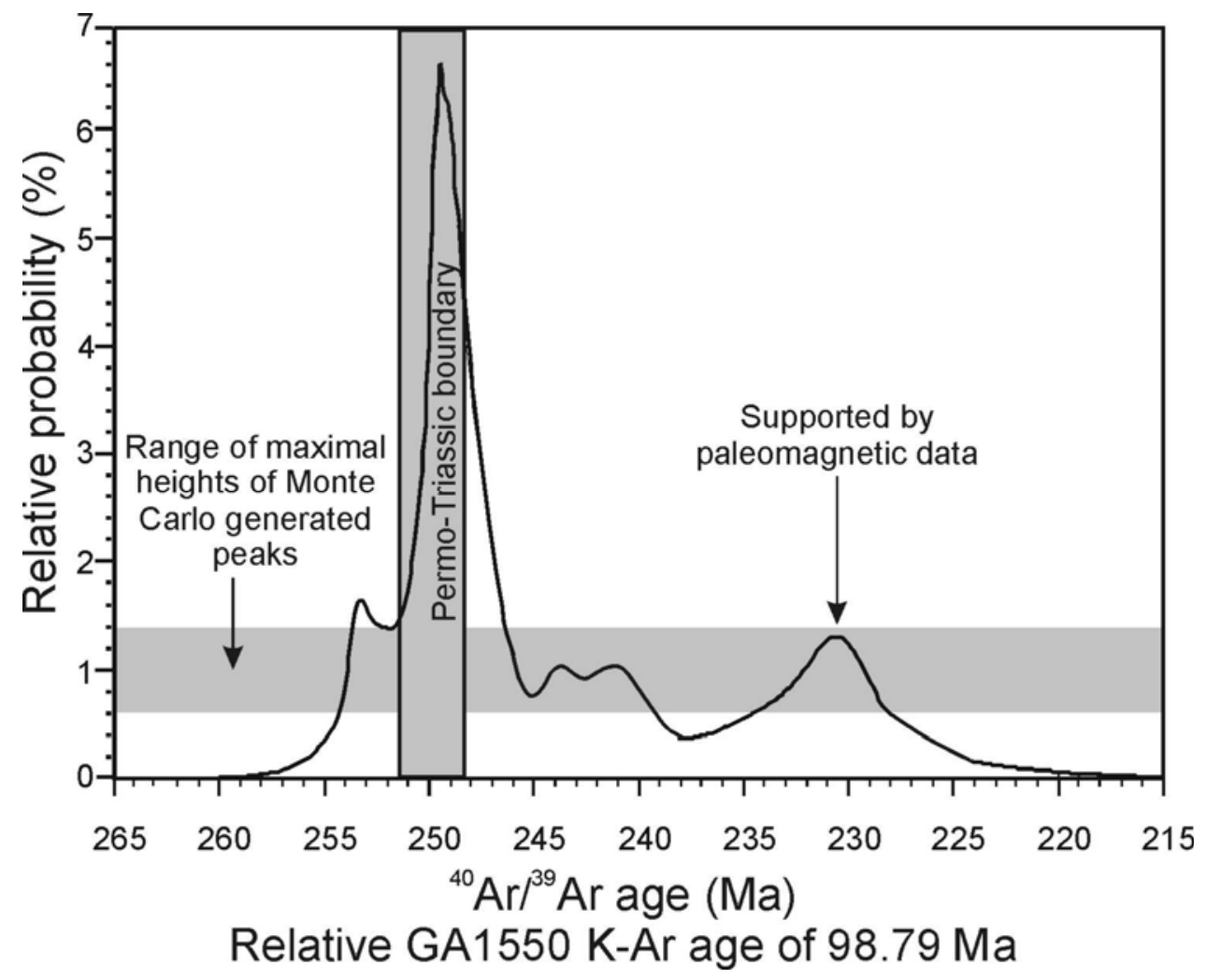

Fig. 3. Relative probability distribution of ${ }^{40} \mathrm{Ar} /{ }^{39} \mathrm{Ar}$ ages (after Ivanov et al., 2006) and original ages (from Baksi and Farrar, 1991; Basu et al., 1995; Dalrymple et al., 1995; Ivanov et al., 2005; 2006; Reichow et al., 2002; Renne and Basu, 1991; Venkatesan et al., 1997; Walderhaug et al., 2005). The Permo-Triassic boundary is from Renne et al. (1995).

\section{Timing of the Siberian Traps LIP}

As mentioned above, the Siberian Traps LIP is a broad term, which includes, in addition to mafic rocks, intrusive rocks of acidic composition. So called anorogenic granitoids (mainly granodiorites and granosyenites) are abundant in the Kuznetsk Basin and its mountain borders and on the Taimyr Peninsula (e.g. Dobretsov et al., 2005; Vernikovsky et al., 2003). The Bolgokhtokh granodiorite intrusion is known in the Noril'sk-Kharaelakh subprovince (e.g. Kamo et al., 2003). An important feature of these anorogenic granitoids is that the oldest are characterized by zircon $\mathrm{U}-\mathrm{Pb}$ ages which are indistinguishable from the Permo-Triassic 
boundary (256 \pm 8, $253 \pm$ 4, $245 \pm 7$ Ma for different massifs of the late Kolba complex within the mountain border of the Kuznetsk Basin (Vladimirov et al., 2001) and $249.0 \pm 5.2$ Ma for the Taimyr (Vernikovsky et al., 2003); the U-Pb age of the Permo-Triassic boundary is debated regarding whether it is $251.4 \pm 0.3 \mathrm{Ma}$ (Bowring et al., 1998) or 252.6 $\pm 0.3 \mathrm{Ma}$ (Mundil et al., 2004). The youngest anorogenic granitoids yielded Middle-Late Triassic ages (231 \pm 11 and $225 \pm 4$ Ma for different massifs of the Monastyrskii complex within the mountains bordring the Kuznetsk Basin (Vladimirov et al., 2001) and $229.0 \pm 0.4$ Ma for the Bolgokhtokh granodiorite intrusion (Kamo et al., 2003). Therefore, the mafic and acidic magmatism of the Siberian Traps was, in general, coeval.

\section{Uplift history}

There is debate about the subsidence/uplift history in the region of the Siberian Traps LIP. Czamanske et al. (1998) noted that volcanic rocks on the Siberian craton erupted within a subsided Tunguska syncline and that these rocks were not preceded by any uplift as would be expected from a plume model (e.g. Campbell and Griffiths, 1990; Campbell, 2005). Saunders et al. (2005) claimed that there was plume-related uplift in the area of the West Siberian Basin and that this uplift is now hidden beneath Mesozoic sedimentary cover.

In Fig. 4 a paleogeographic map of Siberia is shown for the Early Permian (Vinogradov, 1968). The uplift-subsidence pattern shown in Fig. 4 remained virtually unchanged until the Permo-Triassic boundary as reflected by paleogeographic maps reconstructed through different stratigraphic ages (Vinogradov, 1968). Deep rifts in the West Siberian Basin (long linear S-N structures in Fig. 1) developed mainly in the Triassic along a preexisting, long, N-S linear uplift. Uplift commenced at least 25-30 Ma before initiation of Siberian Traps magmatism. Tectonic development of this region may be interpreted in the context of collision between Euro-American (the left part of the Fig. 4), Kazakh (bottom left part of the Fig. 4) and Siberian (central part of the Fig. 4) paleo-continents (Podurushin, 2002). Saunders et al. (2005), however, argued for a relationship between the uplift and a plume. The question whether the subsidence/uplift history recorded for Siberia is associated with a plume is considered in more detail below.

\section{Tectonic setting}


In the Permian and Permo-Triassic, Siberia was a part of Pangea. It was surrounded by convergent plate boundaries with subduction of oceanic plates beneath the continent (Fig. 5) (Nikishin et al., 2002). In present-day coordinates, the southern remnant of the convergent plate boundary is represented by the Mongolia-Okhotsk Suture Zone (MOSZ) (e.g. Zonenshain et al., 1990; Zorin, 1999). It is about $800 \mathrm{~km}$ south of the southeastern end of the Siberian Traps LIP (Fig. 1). Noril'sk is about $2500 \mathrm{~km}$ from the MOSZ. According to paleotectonic reconstructions in the east and southwest (in present-day coordinates) there should be other Permian subduction systems (Fig. 5).

The Transbaikalian volcano-plutonic belt was located between the MOSZ and the Siberian Traps LIP (Fig. 1). This belt developed in the Permian and Triassic and is composed of granitic and syenitic batolites, basaltic and rhyolitic volcanic deposits and dikes (e.g. Yarmolyuk et al., 2001). The origin of the belt is debated. Some authors attribute it to the Siberian Traps LIP (Dobretsov, 2003; 2005) and others consider it an independent intraplate rift phenomenon (Yarmolyuk et al., 2001) or a continental margin Andean-type orogen (Nikishin et al., 2002; Zorin et al., 1998; Zorin, 1999).

\section{Geophysics}

\section{Lithospheric structure}

Upper mantle structure beneath Siberia has been investigated in a number studies using nuclear explosion data (Egorkin, 2001; 2004; Morozov et al., 1999; Pavlenkova, 2006; Pavlenkova and Pavlenkova, 2006; Pavlenkova et al., 2002; Thybo and Perchuc, 1997). Notable features are alternating low- and high-velocity zones in the upper mantle, despite some mismatch between published results on their depths. It is not clear from the seismic data at what depth the lithosphere-asthenosphere boundary lies. Most likely the base of the lithosphere is at the so-called, L-boundary (Pavlenkova, 2006; Pavlenkova and Pavlenkova, 2006; Pavlenkova et al., 2002). Lithospheric low-velocity zones have been interpreted as thin fluid-rich or partial-melt-bearing layers (e.g. Pavlenkova and Pavlenkova, 2006; Pontevivo and Thybo, 2006; Thybo and Perchuc, 1997). A 3D model of the L-boundary is shown in Fig. 1 (from Pavlenkova and Pavlenkova, 2006). The thinnest rounded part corresponds to the position of the Tunguska syncline and the thickest part underlies the West Siberian Basin. The seismic structure disagrees with a thermal model that places the hottest, thinnest parts and the 
coldest, thickest parts of the lithosphere beneath the West Siberian Basin and the Siberian craton, respectively (Artemieva, 2006).

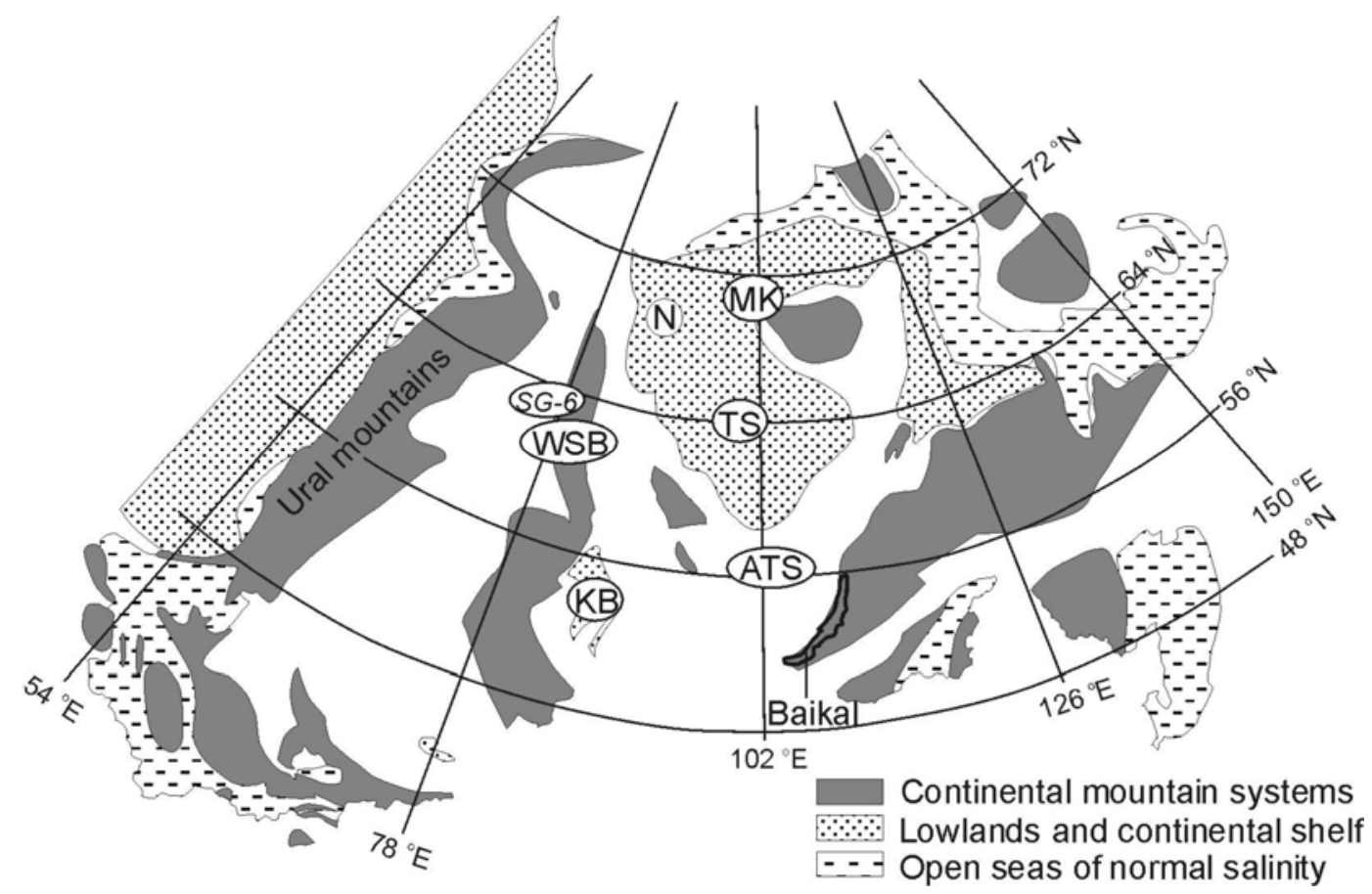

Fig. 4. Paleogeographic reconstruction sketch for the Asselian-Sakmarian (Early Permian, c.a. 280-290 Ma) of Siberia (simplified after Vinogradov, 1968). The location of major PermoTriassic units presented in Fig. 1 and modern geographic coordinates are shown to give orientation. Acronyms as in Fig. 1. The southern distribution of major elements is limited by the border of the former Soviet Union.

\section{Heat-flow}

The Siberian craton is characterized by a low mean value of heat flow of about 40 $\mathrm{mW} / \mathrm{m}^{2}$, which is typical for cratons (Lysak, 1984). According to thermal modeling (Zorin and Vladimirov, 1989; Hyndman et al., 2005) such a low heat flow implies a very long (billions of years) history of stability of the lithosphere. In other words, if the lithosphere was significantly thinned at about 250 Ma then elevated heat flow would be expected. This is not observed. However, calculated thermal thicknesses of the lithosphere vary widely, from 180 to $350 \mathrm{~km}$ (Artemieva, 2006). The thermal thickness of the lithosphere beneath the West Siberian Basin is about $100 \mathrm{~km}$ similar to many mobile belts (Artemieva, 2006). As noted above, these results disagree with seismic data (Fig. 1). 


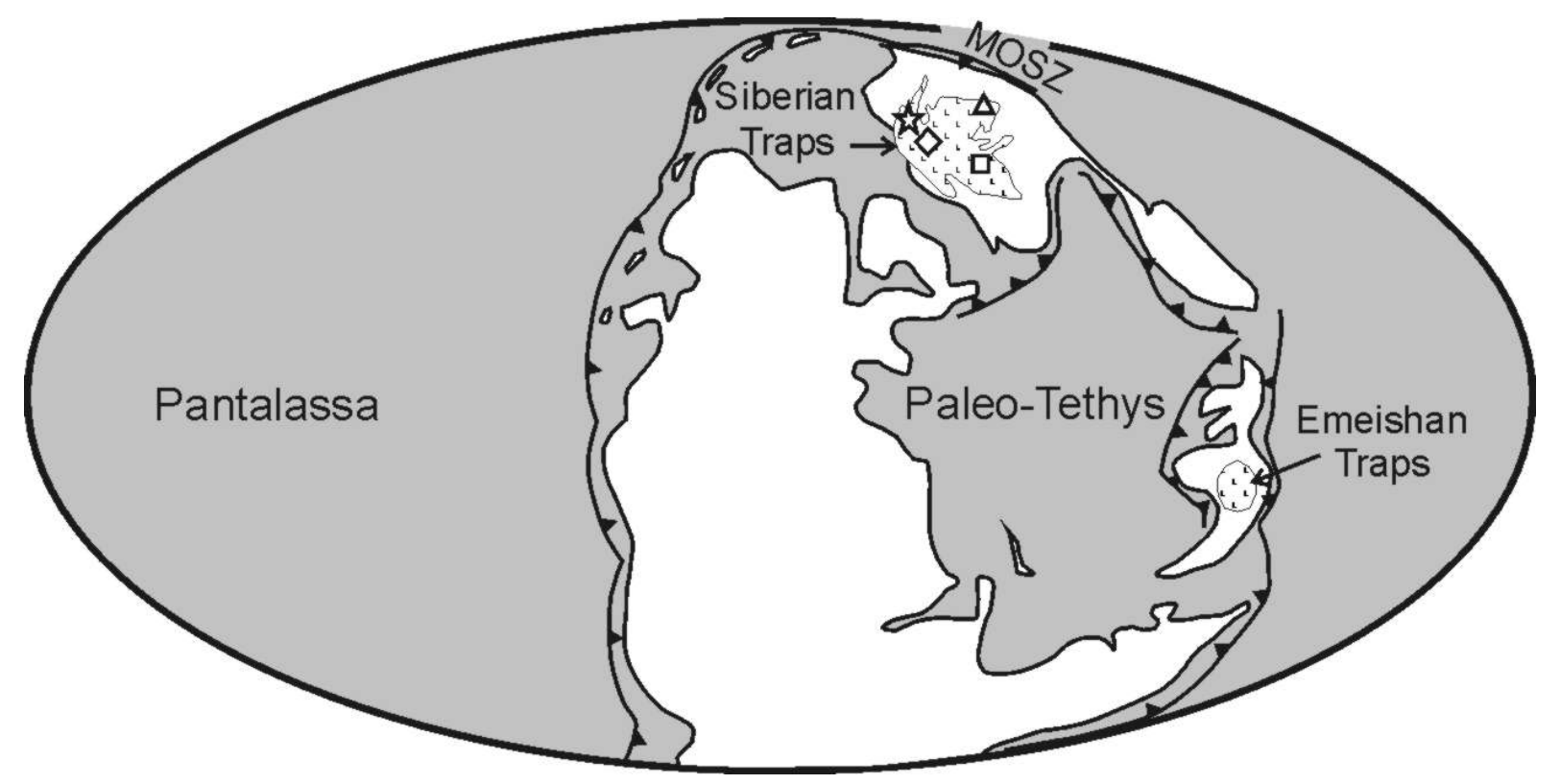

Fig. 5. Paleotectonic map for Pangea in the Late Permian ( $255 \mathrm{Ma})$. White and gray fields represent paleo-landmasses and paleo-oceans, respectively. Solid lines with black triangles mark convergent plate boundaries (simplified after http://www.scotese.com). Approximate positions of the Siberian Traps LIP and MOSZ are shown after Fig. 1. Triangle, square, diamond and star mark approximate location of samples from the Angara-Taseevskaya syncline, the West Siberian Basin, and Noril'sk-Kharaelakh and Maimecha-Kotui subprovinces, respectively, discussed below.

\section{Geochemistry}

Noril'sk-Kharaelakh chemostratigraphic subdivisions

Noril'sk-Kharaelakh sub-province is characterized by the presence of economically important Cu-Ni-Pt deposits (e.g. Naldrett et al. 1992). Due to this more than $3 \mathrm{~km}$ thickness of lava was drilled out and samples recovered horizon-by-horizon were analyzed in great detail (e.g. Lightfoot et al., 1993; Wooden et al., 1993).

Lava strata in Noril'sk-Kharaelakh sub-province were subdivided into several suites and subsuites (formations and subformations; Fedorenko, 1981; Zolotuhin et al., 1984; 1986) (Fig. 6). These suites and subsuites were grouped into three assemblages; Early, Middle and Late, which in practice correspond to three major chemical units; high-Ti, low-Ti -2 and low-Ti - 1 (Fedorenko, 1981; Fedorenko et al., 1996). Distinguishing high- and low-Ti series was done by Lightfoot et al. (1993) on basis of a $\mathrm{TiO}_{2}-\mathrm{Mg} \#$ diagram. Ivanov and Balyshev

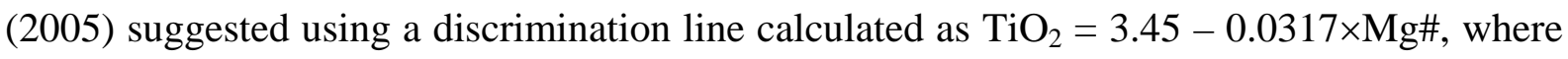
$\mathrm{Mg} \#$ is $\mathrm{Mg} /\left(\mathrm{Mg}+0.85 \mathrm{Fe}_{\text {total }}\right)$ (elements are presented in atomic units and $\mathrm{Fe}_{\text {total }}$ is calculated from $\mathrm{FeO}_{\text {total }}$ ). High-Ti rocks are characterized by higher ratios of light and middle rare earth 
elements (REE) to heavy REE compared to the low-Ti rocks. For example, Fedorenko et al. (1996) separated high- and low-Ti series rocks by a divider of $\mathrm{Gd} / \mathrm{Yb}=2$. These authors used $\mathrm{Th} / \mathrm{U}$ ratio to distinguish two subseries of the low-Ti rocks; lower Th/U generally below 3.5 for the low-Ti - 1 subseries and higher $\mathrm{Th} / \mathrm{U}$ of above 3.2 for the low-Ti - 2 subseries. In the $\Delta 8 / 4$ - Th/U diagram, basalts of the Noril'sk-Kharaelakh sub-province are separated into two groups (Fig. 7); a group of DUPAL basalts with $\Delta 8 / 4>\sim 50$ and Th/U $>\sim 2.5$ and also with systematically more radiogenic $\mathrm{Sr}$ and Nd isotopes, and a group of non-DUPAL basalts with $\Delta 8 / 4<\sim 70, \mathrm{Th} / \mathrm{U}<\sim 3.0$ and non-radiogenic $\mathrm{Sr}$ and $\mathrm{Nd}$ isotopes $(\Delta 8 / 4$ is calculated as $\left.100 \times\left[\left({ }^{208} \mathrm{~Pb} /{ }^{204} \mathrm{~Pb}\right) /\left(1.209 \times{ }^{206} \mathrm{~Pb} /{ }^{204} \mathrm{~Pb}\right)+15.627\right)\right]$ (Hart, 1984) reflecting a shift in the ${ }^{208} \mathrm{~Pb} /{ }^{204} \mathrm{~Pb}-{ }^{206} \mathrm{~Pb} /{ }^{204} \mathrm{~Pb}$ diagram from a linear regression line through North Atlantic MORBs. DUPAL is an acronym of the names of Dupré and Allègre (1985). It appears that DUPAL and non-DUPAL basalts alternate in the continuous lava pile (Fig. 6). Changes between different chemostratigraphic subdivisions are very sharp without any mixing trends on isotopic and trace element diagrams (Fig. 7).

DUPAL basalts are systematically depleted in Pt and Pd (usually at the detection limit of neutron activation with the exception of part of the Tk suite; Wooden et al. (1993)). NonDUPAL basalts yield higher concentrations of Pt and Pd distributed in a Gaussian fashion (Fig. 8). DUPAL rocks are generally more enriched in the radiogenic isotopes $\mathrm{Sr}$ and $\mathrm{Nd}$, though there is a large overlap. Initial values at $250 \mathrm{Ma}$ are as follows: ${ }^{87} \mathrm{Sr} /{ }^{86} \mathrm{Sr}$ from 0.7053 to 0.7088 and $\varepsilon N d$ from 2 to -11 for DUPAL and ${ }^{87} \mathrm{Sr} /{ }^{86} \mathrm{Sr}$ from 0.7041 to 0.7072 and $\varepsilon N d$ from 4.2 to -2.5 for non-DUPAL rocks (where $\varepsilon N d \equiv\left(\left[{ }^{143} \mathrm{Nd} /{ }^{144} \mathrm{Nd}\right]_{\text {Sample }} /\left[{ }^{143} \mathrm{Nd} /{ }^{144} \mathrm{Nd}\right]_{\text {Chondrite }}\right.$ - 1) $\times 10000$ at $250 \mathrm{Ma}$ ). Limited data for osmium isotopes shows that Tk DUPAL rocks and $\mathrm{Gd}_{2}$ non-DUPAL rocks have similar positive $\gamma \mathrm{Os}$ values (3.4-6.5 and 5.3-6.1, respectively, where $\gamma \mathrm{Os} \equiv\left(\left[{ }^{187} \mathrm{Os} /{ }^{188} \mathrm{Os}\right]_{\text {Sample }} /\left[{ }^{187} \mathrm{Os} /{ }^{188} \mathrm{Os}\right]_{\text {Chondrite }}-1\right) \times 100$ at $250 \mathrm{Ma}$; Horan et al., 1995).

Such distribution of Pt and Pd together with radiogenic isotopes and trace-element data can be interpreted as evidence for an eclogitic source of the DUPAL basalts of the Noril'sk-Kharaelakh subprovince. It is worth mentioning that DUPAL basalts are interpreted as derivates of an eclogitic (recycled crustal) source everywhere in the world (see discussion in Ivanov and Balyshev, 2005), including the classical DUPAL of the Indian Ocean (e.g. Escrig et al., 2004; Meyzen et al., 2005).

Fig. 9 gives an overview of trace element patterns in different chemostratigraphic units of the Noril'sk-Kharaelakh subprovince. It may be seen that there two major types; with trace element concentrations (1) at a level of ocean island basalts (OIB) and (2) at a level of 
enriched mid-ocean ridge basalts (E-MORB). The $\mathrm{Nd}$ suite is enriched in the most incompatible elements ( $\mathrm{Rb}$ to $\mathrm{K}$ ) like OIB, but depleted in more compatible elements ( $\mathrm{Sr}$ to $\mathrm{Yb})$ like E-MORB. Despite the similar level of concentrations the trace element patterns exhibit more irregular patterns than OIB and E-MORB. A general feature of most suites is depletion of Ta relative La and K. The Gd suite is an exception. However, it differs from EMORB by depletion of $\mathrm{K}$ and $\mathrm{Ba}$ and absence of depletion in $\mathrm{Pb}$ relative to Ce and Pr. The $\mathrm{Iv}_{1}$ subsuite is similar to OIB, but differs from it by depletion of $\mathrm{Sr}$, and enrichment of $\mathrm{Ba}$, Th, $\mathrm{U}$ and $\mathrm{P}$ relative neighboring elements.

Heavy REEs are compatible (e.g. Green, 1994) in garnet and therefore melting of garnet-bearing mantle will produce particular REE-patterns in the derivative melts with high light-to-heavy REE ratios at low heavy REE concentrations. In spinel, heavy REEs are incompatible, producing low light-to-heavy REE ratios with highly variable concentrations of the heavy REEs (compare Models 1 and 2 in Fig. 10). This reasoning would lead to estimation of the source mineralogy of Siberian Traps basalts to lie within the shallow (less than 50-60 km depth) spinel stability field of the mantle. The lithospheric thickness is at least $180 \mathrm{~km}$ thick beneath the Tunguska syncline and over than $240 \mathrm{~km}$ thick beneath Noril'sk. The lithosphere could not be thinned to $60 \mathrm{~km}$ and restored back to the normal cratonic value in only 250 Ma (Zorin and Vladimirov, 1989; Hyndman et al., 2005). Therefore, either voluminous melting appeared solely within cold cratonic lithosphere, which is unlikely from the thermal point of view, or geochemical data require another explanation. From Mg-number variations, only a few stratigraphic units at Noril'sk can be regarded as containing primary mantle-derived melts. These are the non-DUPAL $\mathrm{Gd}_{2}$ subsuite and the DUPAL Tk suite (Figs. 6 and 10). Their compositions can be modeled as $~ 18 \%$ and $\sim 45-70 \%$ degrees of partial melting from garnet lherzolite and eclogite, respectively (Fig. 10). All other stratigraphic units contain variably differentiated melts. Due to the differentiation these melts are characterized by higher $\mathrm{Yb}$ content. It should be noted that the modeling presented in Fig. 10 serves rather to show in principle the possibility of derivation of the Siberian Traps basalts from garnet-bearing sources with consequent differentiation, than to find the best-fitting solution for each suite.

\section{The Maimecha-Kotui sub-province}

In the Meimecha-Kotui subprovince a lava stratum about $4 \mathrm{~km}$ thick formed. Initial eruptions of the Arydzhansky high-Ti suite lava took place probably as early as the Late 
Permian as shown from ${ }^{40} \mathrm{Ar} /{ }^{39} \mathrm{Ar}$ dating (Basu et al., 1995), but this was questioned by a Permo-Triassic U-Pb perovskite age (Kamo et al., 2003; see section on dating below). A large part of the stratum consists of low-Ti basalts similar to the Noril'sk-Kharaelakh low-Ti basalts. The uppermost Maymechinsky suite was preceded by the high-Ti Delkansky suite (Fedorenko and Czamanske, 1997). High-Ti lavas including unusual picritic lavas meimechites, comprise about $50 \%$ by volume. The Maymechinsky suite makes up to more than $1 / 3$ of the total lava sequence. This suite is intruded by carbonatites with a U-Pb baddeleyite age of $250.2 \pm 0.3 \mathrm{Ma}$ (Kamo et al., 2003).

Meimechites are of particular interest. These are unusual high $\mathrm{Mg}$ ( $\mathrm{MgO}>18$ wt. \%), high $\mathrm{Ti}\left(\mathrm{TiO}_{2}>1\right.$ wt. \%) mafic and ultramafic rocks $\left(\mathrm{SiO}_{2}<52\right.$ wt. \%) (Le Bas and Streckeisen, 1991). They are characterized by porphiric texture with olivine and serpentine phenocrysts in a dark feldspar-free groundmass. Primary biotite also occurs occasionally (e.g. Fedorenko and Czamanske, 1997). They exhibit enriched OIB-type trace element patterns without Ta-Nb depletion and depleted $\mathrm{Sr}$ and Nd isotopes $\left({ }^{87} \mathrm{Sr} /{ }^{86} \mathrm{Sr}\right.$ from 0.7030 to 0.7034 and $\varepsilon N d$ from 2.8 to 5.9; Arndt et al., 1995). Arndt et al. (1995) concluded that it is not evident from what source (lithospheric or sublithospheric) the meimechites originated. Kogarko and Ryabchikov (1995) suggested they formed from interaction of sublithospheric melts with lithospheric refractory harzburgites. In both cases a low degree of melting for the primary meimechite melts was accepted (Arndt et al., 1995; Kogarko and Ryabchikov, 1995).

A high Mg content is usually considered to be evidence for high temperature. Sobolev et al. (1991) suggested on the basis of analysis of melt inclusions in the meimechites and numerical calculations that meimechites were derived from a depth of 230-300 $\mathrm{km}$ at a temperature of $1800-1900{ }^{\circ} \mathrm{C}$ due to mantle upwelling of a plume from greater depths $(\sim 700$ $\mathrm{km})$. Elkins-Tanton et al. (submitted) performed an experimental study of meimechites and concluded that their primary melts were derived from a source with as much as 1 wt.\% of $\mathrm{H}_{2} \mathrm{O}$ at about $180 \mathrm{~km}$ depth and a temperature of $1700{ }^{\circ} \mathrm{C}$. They noted that incorporation of additional $\mathrm{H}_{2} \mathrm{O}$ and $\mathrm{CO}_{2}$ would lower the temperature to $1550{ }^{\circ} \mathrm{C}$. 


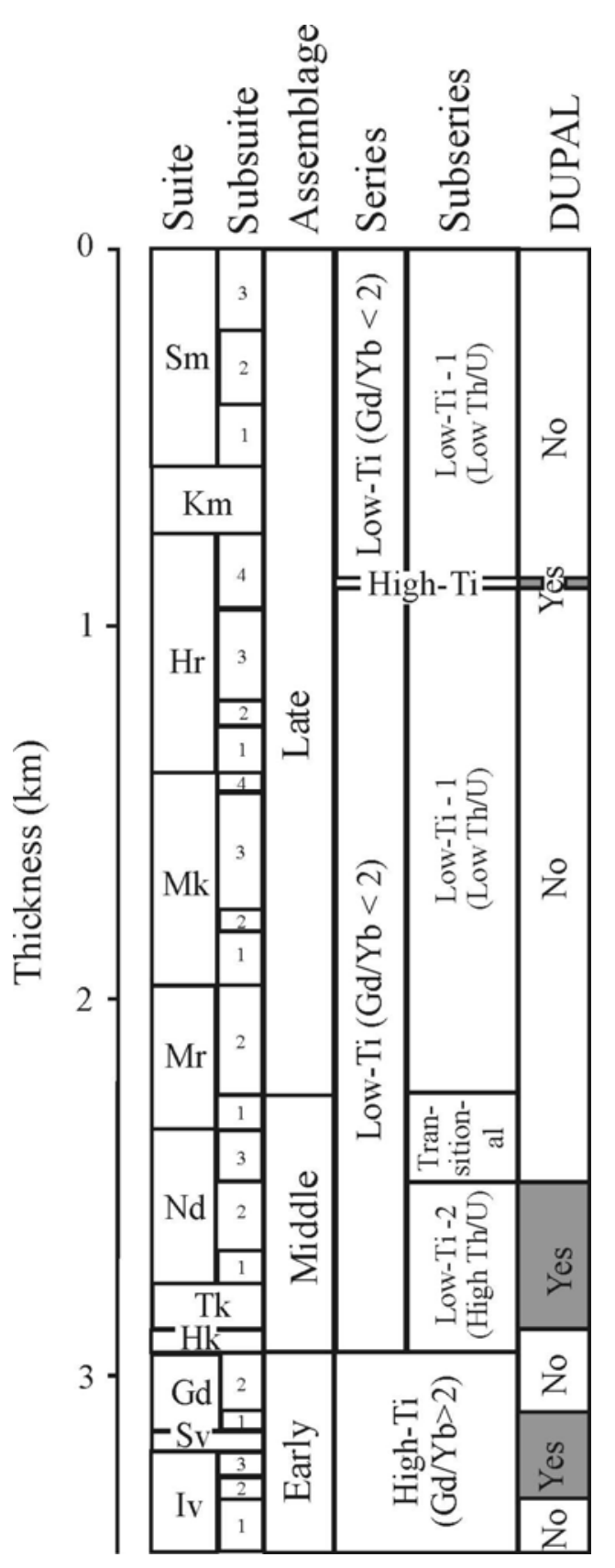

Fig. 6. Chemostratigraphic subdivision of lavas at Noril'sk (modified from Lightfoot et al., 1993; Wooden et al., 1993; Fedorenko et al., 1996; Al'mukhamedov et al., 2004). DUPAL is defined on the basis of the $\Delta 8 / 4-\mathrm{Th} / \mathrm{U}$ diagram (Fig. 7), where $\Delta 8 / 4$ is the vertical deviation from linear regression for North Atlantic mid-ocean ridge basalts on the ${ }^{208} \mathrm{~Pb} /{ }^{204} \mathrm{~Pb}-$ ${ }^{206} \mathrm{~Pb} /{ }^{204} \mathrm{~Pb}$ diagram (Hart, 1984). Suite names: Ivakinsky, Syverminsky, Gudchikhinsky, Hakanchansky, Tuklonsky, Nadezhdinsky, Morongovsky, Mokulaevsky, Haraelakhsky, Kumginsky and Samoedsky. Low-Ti lavas make up $80 \%$ of the lava sequence. DUPAL-type lavas make up to about $20 \%$ of the lava sequence in both the high- and low-Ti units. 


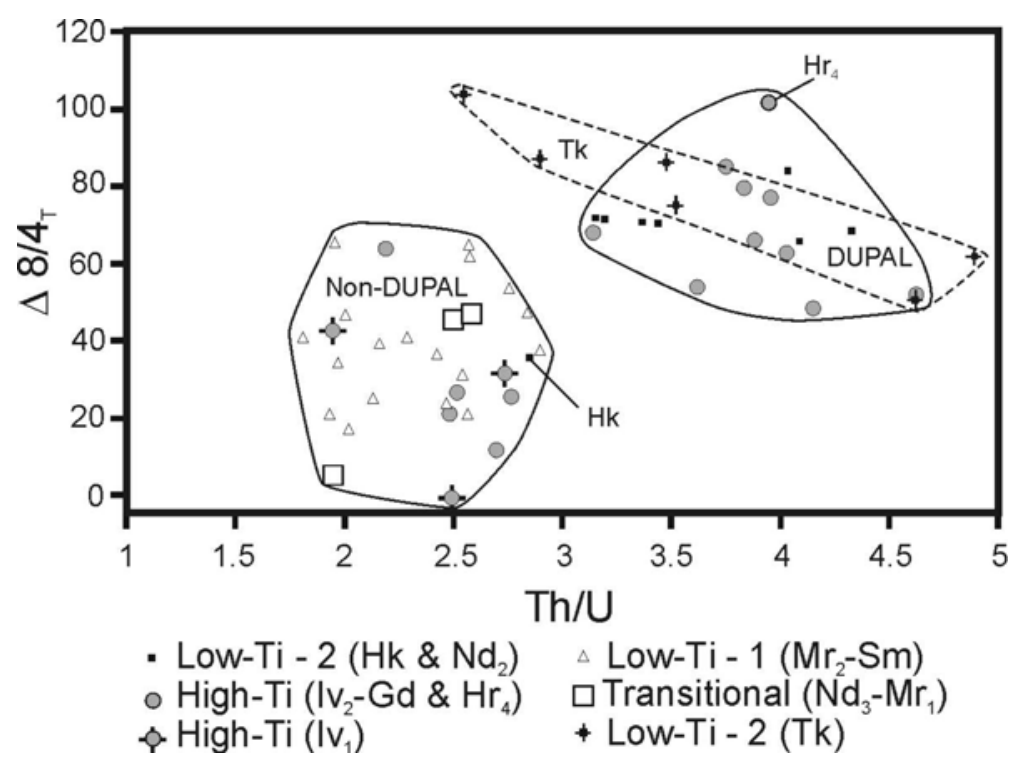

Fig. 7. Subdivision of basaltic lavas at Noril'sk into DUPAL and non-DUPAL subsets on the basis of $\mathrm{Th} / \mathrm{U}$ and $\Delta 8 / 4$ ratios, where $\Delta 8 / 4$ is calculated as $100 \times\left[\left({ }^{208} \mathrm{~Pb} /{ }^{204} \mathrm{~Pb}\right) /\left(1.209 \times\left({ }^{206} \mathrm{~Pb} /{ }^{204} \mathrm{~Pb}\right)+15.627\right)\right]$ (Hart, 1984). The original data for the analysis are taken from the most complete source of data (Wooden et al., 1993). Subscript $\mathrm{T}$ refers to initial values at $250 \mathrm{Ma}$.
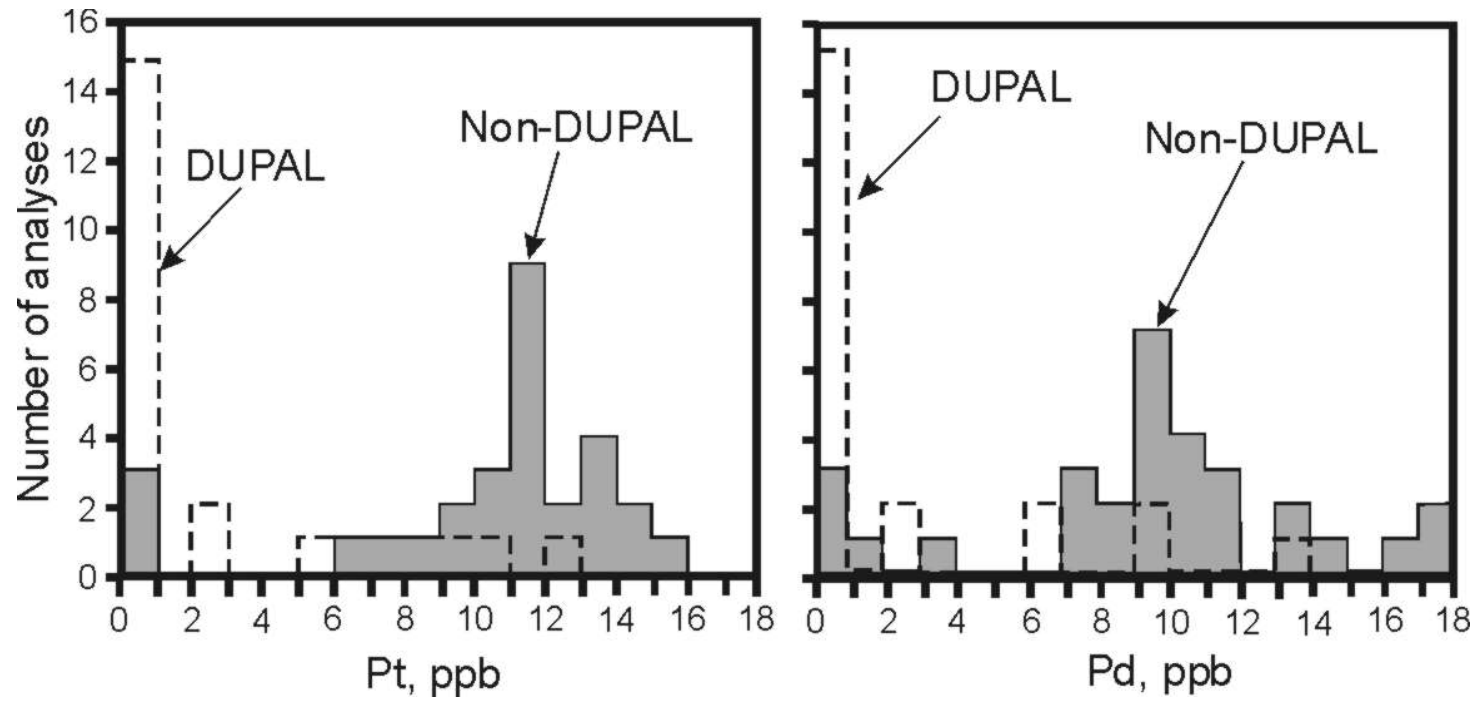

Fig. 8. Distribution of Pt and Pd in basalts from the Noril'sk-Kharaelakh subprovince. All low $\mathrm{Pt}$ and Pd concentrations in non-DUPAL basalts belong to the $\mathrm{Iv}_{1}$ subsuite. Most of the high Pt and Pd concentrations in DUPAL basalts are from samples of the Tk suite. Original data are from Wooden et al. (1993). 


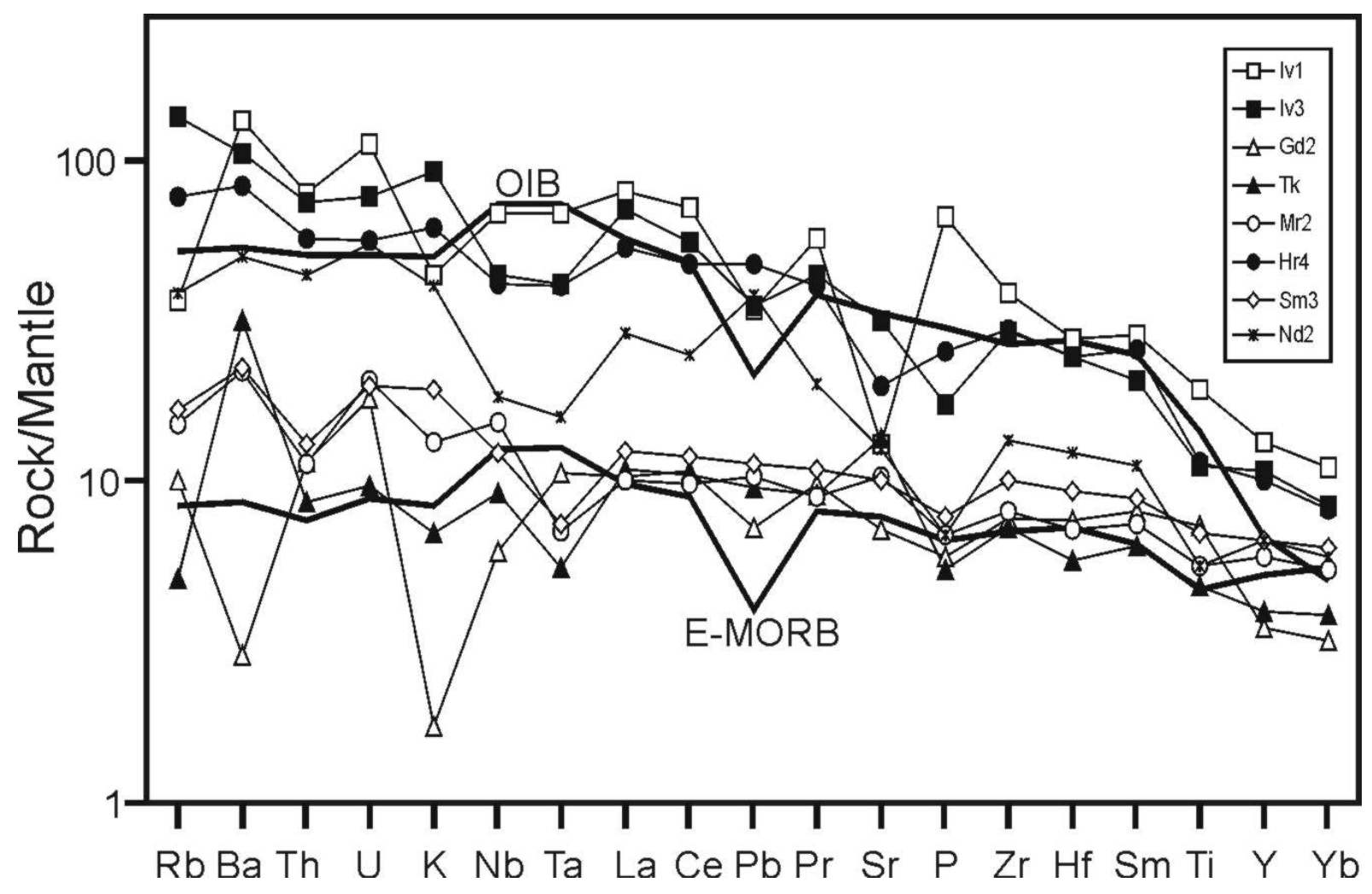

Fig. 9. Primitive mantle normalized trace element diagrams for representative samples of different chemostratigraphic units of the Noril'sk-Kharaelakh subprovince. Data are from Wooden et al. (1993). Hypothetical pure compositions of ocean island basalt (OIB) and enriched mid-ocean ridge basalt (E-MORB) are shown after Sun and McDonough (1989). Primitive mantle composition is after McDonough and Sun (1995).

The West Siberian Basin and Angara-Taseevskaya syncline

Medvedev et al. (2003) and Reichow et al. (2005) provided analytical data on almost the same samples recovered from a number of drill-holes in the West Siberian Basin. Volcanic rock compositions vary from mafic to acidic. If only mafic rocks are considered, according to these authors' data and the classification scheme of Fedorenko et al (1996) all but one sample belongs to the low-Ti basalts (tholeiites and shoshonites). Shoshonites and tholeiites exhibit similar island-arc-basalt-like (IAB-like) trace element patterns with $\mathrm{Ba}, \mathrm{U}$, $\mathrm{Pb}$, Sr relative enrichment and $\mathrm{Nb}$ relative depletion, though shoshonites are characterized by higher concentrations of most trace elements (Fig. 11). Dolerite sills of the AngaraTaseevskaya syncline are characterized by lower concentrations of the trace element at the level of E-MORB. But the IAB-like trace-element pattern is also typical for the dolerite sills. Ivanov et al. (submitted) noted that Usol'skii and Tolstomysovskii sill dolerites are geochemical analogues of the low- $\mathrm{Ti}-1$ subseries and low- $\mathrm{Ti}-2$ subseries (Tk suite) of the 
Noril'sk-Kharaelakh subprovince, respectively. This is reflected in almost identical trace element patterns and $\mathrm{Sr}$ isotopes.

Petrographic examination of dolerite sills revealed that some samples contain primary magmatic mica, probably biotite (Fig. 12).
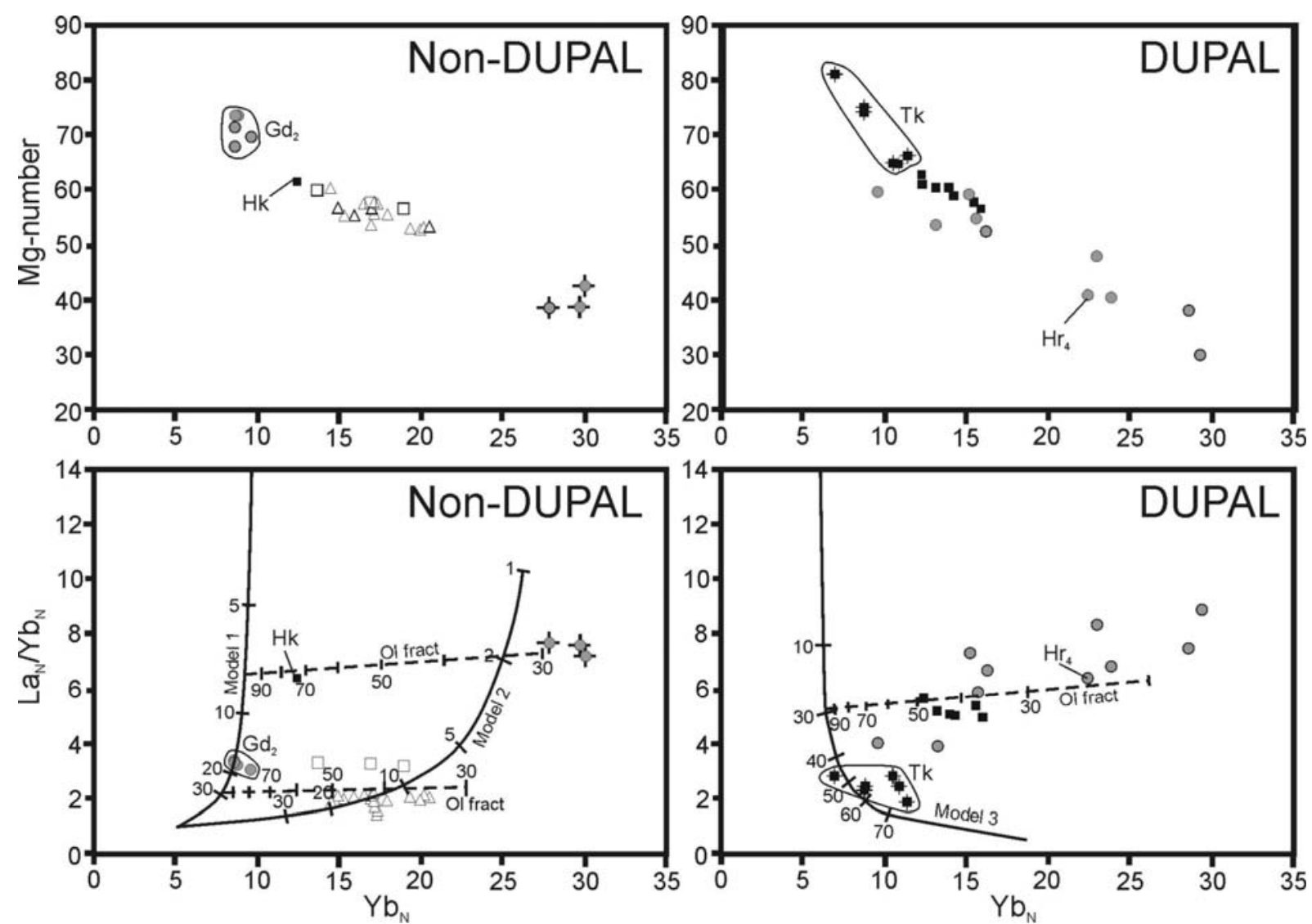

Fig. 10. $\mathrm{La}_{\mathrm{N}} / \mathrm{Yb}_{\mathrm{N}}$ and Mg-number versus $\mathrm{Yb}_{\mathrm{N}}$. The subscript ${ }_{\mathrm{N}}$ refers to chondrite-normalized values (McDonough and Sun, 1995). Models 1, 2 and 3 show equilibrium partial melting of garnet lherzolite, spinel lherzolite and eclogite, respectively. Numbers close to the curves represent percentage of partial melting. Dashed lines represent equilibrium crystallization of olivine. Numbers close to the lines represent percentage of remaining magma. The equation of Shaw (1970) was used for the calculations. The compositions of the modeled sources of melting were the following: (1) garnet lherzolite $-52 \%$ of Ol, $30 \%$ of Opx, $15 \%$ of Cpx, 3\% of Gt; (2) spinel lherzolite - 55\% of Ol, 15\% of Opx, 15\% of Cpx, 15\% of Spl; (3) eclogite $55 \%$ of Cpx, 45\% of Grt; (where Ol, Opx, Cpx, Grt and Spl are olivine, orthopyroxene, clinopyroxene, garnet and spinel, respectively). Concentrations of $\mathrm{La}$ and $\mathrm{Yb}$ in lherzolites and eclogite were accepted as 5 times chondritic values and as in N-MORB, respectively (McDonough and Sun, 1995; Sun and McDonough, 1989). Mineral/melt distribution coefficients are: Ol and Opx - Dunn and Sen (1994); Cpx - Hart and Dunn (1993); Grt Zack et al. (1997); Spl - Kelemen et al. (1990). Compositions of the Siberian Traps at Noril'sk are after Wooden et al. (1993). Symbols as in Fig. 7. 


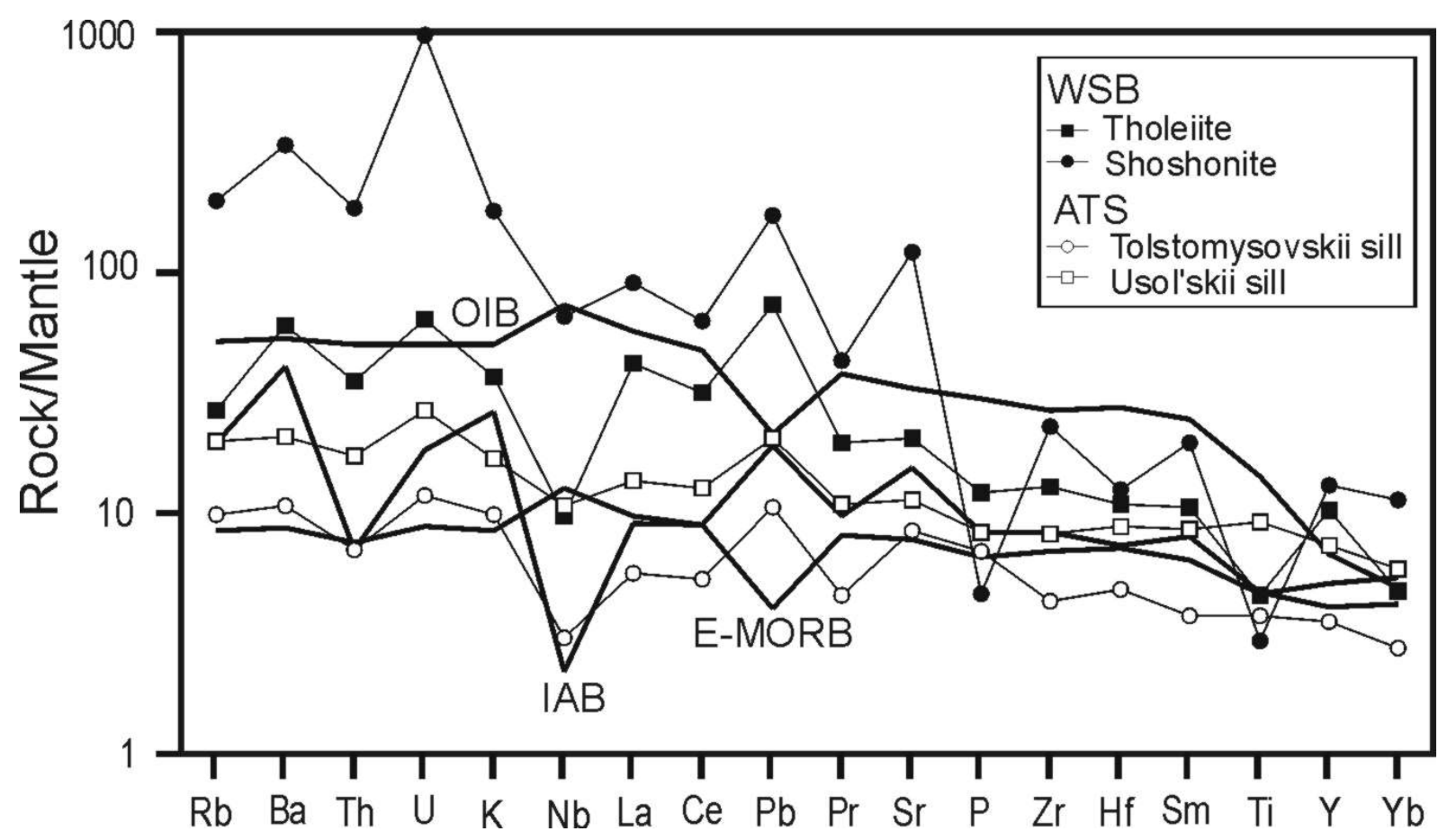

Fig. 11. Primitive mantle normalized trace-element diagrams for representative samples from West Siberian Basin and Angara-Taseevskaya syncline. Data are after Medvedev et al. (2003) and Ivanov et al. (submitted), respectively. Hypothetical pure compositions of ocean island basalt (OIB) and enriched mid-ocean ridge basalt (E-MORB) are shown after Sun and McDonough (1989). The average of high magnesium basalts from Klyuchevskoi volcano, Kamchatka is shown as representative of island-arc basalt (IAB) (Dorendorf et al., 2000). Primitive mantle composition is after McDonough and Sun (1995).

\section{DISCUSSION: EVIDENCE AND MODELS}

\section{Impact model}

Interest in the impact model for the origin of the Siberian Traps FBP is mainly due to the idea that large extraterrestrial body collisions with the Earth cause biotic mass extinctions; an idea, which was originally suggested for KT boundary (Alvarez et al., 1980) and also debated over years for the PT boundary (see Erwin et al., 2002 for a review). Two varieties of the impact model can be discussed in relation to the Siberian Traps FBP; the impact site was somewhere within the Siberian Traps FBP (Jones et al., 2002) and the impact site was antipodal to the Siberian Traps FBP (Hagstrum, 2005). The former model has related Cu-NiPt mineralization in the Siberian Traps and impactor material. The latter model could explain absence of a PT impact crater because of its disappearance due to subduction of the Pantalassa oceanic flow (see Fig. 5). In any case, the sizes of the impactor and the impact crater must be 
of the order of the KT meteorite and the Chicxulub crater or even larger ( $\geq 10-15 \mathrm{~km}$ for the impactor and $\geq 200$-300 km for the crater). However, either of these two impact models meets irresolvable problems in explaining the volume of the outpoured basaltic magma and the size of the Siberian Traps LIP (Fig. 1; Table 1). Various calculations suggest that an impact of such a size may initiate magma generation of order of $10^{5} \mathrm{~km}^{3}$ (Gilkson, 1999; Ivanov and Melosh, 2003). If an initial hot geotherm and thin oceanic lithosphere is considered, an increase in magma volume up to $2.5 \times 10^{6} \mathrm{~km}^{3}$ is expected due to the additional effect of decompression (Jones et al., 2005). As noted by Jones et al. (2005) the largest impact would generate a footprint up to $1000 \mathrm{~km}$ in diameter if occurs on oceanic lithosphere but much smaller if occurs on continental lithosphere. Therefore, the extent of the Siberian Traps LIP (Fig. 1) is too large even for the most favored conditions of the impact model.

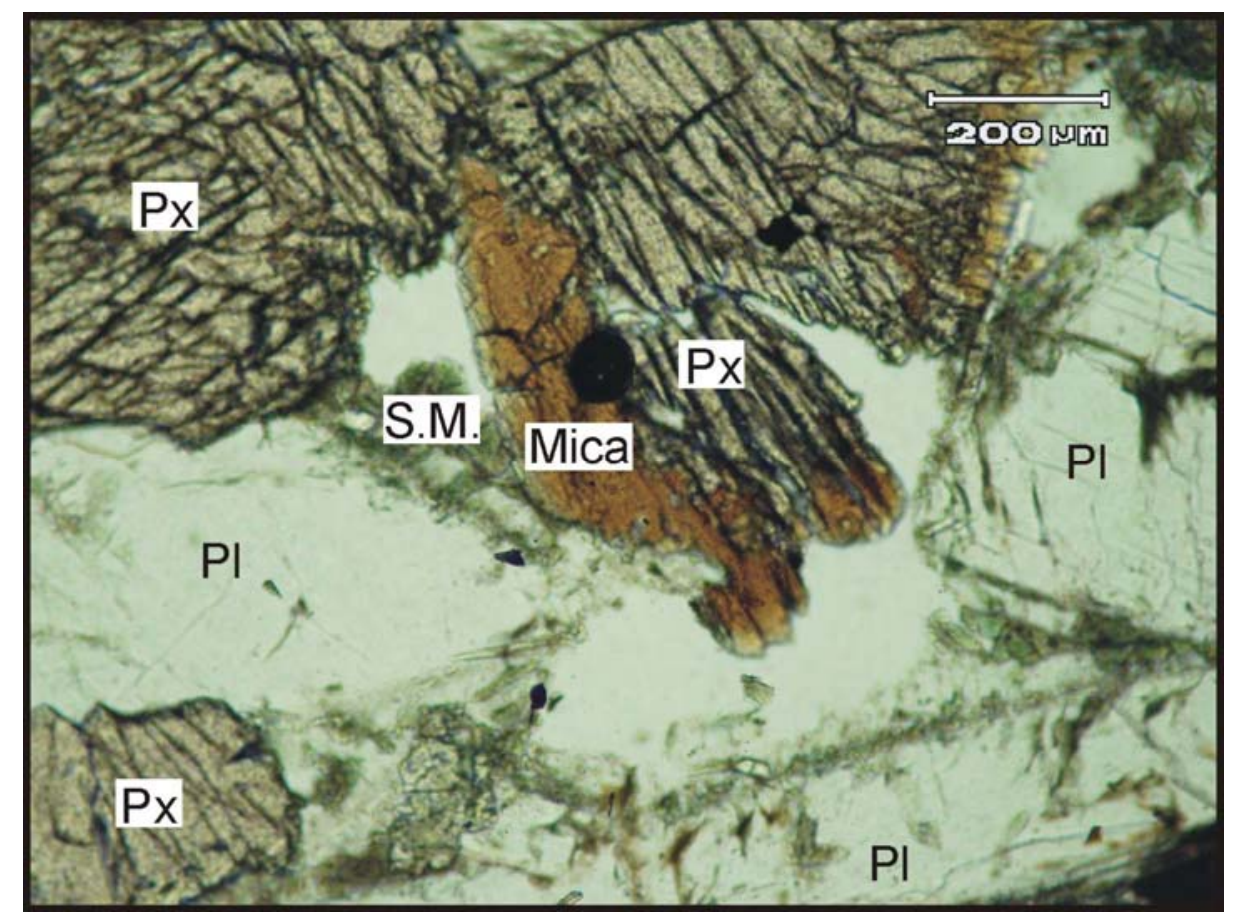

Fig. 12. A view of a dolerite thin-section (sample ST-21-05 from Tolstomysovskii sill) under a polarized microscope (parallel nicols). Px - pyroxene, Pl - plagioclase, S.M. - secondary mineral developed on plagioclase. Small black dots - ore minerals. Olivine is rare (out of the image). Mica crystals show intergrowths with, mainly, pyroxene. Dolerite sill geology is described in detail by Feoktistov (1979) and briefly by Ivanov et al. (2005).

Besides the abovementioned problems, a large impact would leave geochemical fingerprints in PT boundary sedimentary records. All earlier findings of such fingerprints have been either disproved or at least doubts brought into question (see critique by Koeberl et 
al., 2002 and Erwin et al., 2002 for a review). The apparently prolonged volcanism of the Siberian Traps FBP starting in the Late Permian and continuing until the end of the Middle Triassic is also against the impact model.

\section{Plume model}

To explain the large size of LIPs, Campbell and Griffiths (1990) suggested a starting plume head model, in which a plume has a particular flattened head and thin tail structure. The head is responsible for the voluminous eruptions. As recently pointed out by Campbell (2005) this model gives testable predictions: (1) new plumes consist of a large head and a thin tail, (2) flattened plume heads should be 2000 to $2500 \mathrm{~km}$ in diameter, (3) plumes must originate from a hot boundary layer, probably the core-mantle boundary, (4) both head and tail should erupt high-temperature picrites, (5) the temperature excess of a plume head is highest at the center of the head and decreases towards the margin, (6) picrites should erupt early during flood volcanism and be most abundant near the center of the plume head and less abundant towards the margin, (7) flood basalt should be preceded by domal uplift of 500 to $1000 \mathrm{~m}$ at the center of the dome. Not all of the listed predictions can be tested for an ancient event such as Siberian Traps FBP without additional assumptions.

(1) For example, we do not know wether a Siberian plume, if existed, had head-andtail structure. According to the formulated plume model the head and tail should give a LIP (FBP) and a continuous chain of volcanoes, respectively (Campbell, 2005). A continuous volcanic chain from the Siberian Traps LIP to any active or more recent hotspot is unknown, though some authors speculate that there is a link between Iceland and the Siberian Traps and that the volcanic track between them is hidden beneath the Polar ocean (e.g. Burke and Torsvik, 2004; Chernysheva et al., 2005).

(2) The Siberian Traps LIP is larger than the expected 2000-2500 km circular flattened head (Fig. 1). Actually, the Siberian Traps do not exhibit rounded structure, but rather its volcanic rocks filled preexisting elongated depressions (compare Fig. 1 and Fig. 4).

(3) Depth of origin of the supposed plume cannot be inferred by any means, though Sobolev et al. (1991) interpreted their data on meimechites to suggest that these melts came from as deep as $700 \mathrm{~km}$. On the basis of these extrapolations the depth of origin and how to find it, are both unclear.

(4) Picrites are known from many parts of the Siberian Traps LIP. However, at least, some are cumulates (for example, picrites within sills of the Angara-Taseevskaya syncline). 
Detailed petrographic studies are required from all over the Siberian Traps FBP to test a primary versus cumulative origin of the picrites.

(5) The temperature profile of the mantle at $250 \mathrm{Ma}$ is not known. However, we may expect the greatest erosion of the lithosphere where the plume is hottest, i.e. at its center. The geographical center of the Siberian Traps LIP is the western part of the Tunguska syncline (Fig. 1). The lithosphere there is significantly thinned (Fig. 1). This is in agreement with prediction. However, because of the absence of uplift in Tunguska syncline (Fig. 4) the plume center was placed beneath the West Siberian Basin by Saunders et al. (2005). The lithospheric thickness is large there (Fig. 1).

(6) In the Noril'sk-Kharaelakh subprovince, picrites are recorded within the Gd and Tk suites (see Fig. 6 for stratigraphic location of the suites). These are not the earliest suites. In Maimecha-Kotui subprovince, the most magnesium, and expectedly highest temperature, melts were erupted at the very end of the Permo-Triassic volcanism pulse, once more the opposite of what is predicted. If we locate the plume center in the geographical center of the Siberian Traps LIP, then the meimechites appear to be at the margin of the supposed plume head. If instead we assume that the meimechites mark the position of the plume center, then the plume would be highly asymmetric even if the FPB extended into the Kara and Laptev undersea areas (Fig. 1).

(7) There was no domal uplift at the center of suggested plume head. Both the Tunguska and Maimecha-Kotui subprovinces are located in subsided areas (Fig. 4). Burov and Guillou-Frottier (2005) calculated that a plume beneath a continent may result in a complex pattern of uplifts and sedimentary basins. They even show that a subsidence may overlie the center of the plume head. One may then question the testability of the domal uplift prediction, when the presence of uplift prior to emplacement of the Emeishan Traps (He et al., 2003) is taken as classical evidence of a plume (Campbell, 2005), but presence of subsidence prior to eruption of the Siberian Traps is also taken as evidence of a plume. However, even incorporation of a 'realistic lithosphere model' cannot explain the observed uplift/subsidence pattern (Fig. 4) in the context of the plume model. According to the calculations of Burov and Guillou-Frottier (2005) while a plume is entering the upper mantle (crossing the $660 \mathrm{~km}$ discontinuity) a small to moderate uplift occurs above the plume center. After a few Ma the uplift may be converted to deep subsidence. The subsidence in the Tunguska and MaimechaKotui subprovinces were originated long before the initiation of the volcanism (at least 25-30 Ma before) and these subsidences remained virtually unchanged until the Permo-Triassic volcanism (Vinogradov, 1968). 
There are number of possible explanations for why plume-expected evidence is not observed in the Siberian Traps (for example, picrite melts could pond in crustal magmatic chambers, and not reach the surface). However, a successful theory cannot be built on nonobserved evidence. In my view, much available evidence contradicts the predictions of the plume model, while, data on paleogeography argue strongly against the plume model. The only supporting evidence is the high calculated temperatures for the meimechite melts (Sobolev et al., 2001; Elkins-Tanton et al., submitted), which is hard to explain in terms of conventional thinking regarding a "dry” peridotitic source of melt. The addition of volatiles lowers the melting temperature required to produce meimechites (Elkins-Tanton et al., submitted). The effect of volatile addition thus requires further thorough investigation.

Geochemical aspects of the plume model have been considered for the Noril'skKharaelakh subprovince by Wooden et al. (1993). These authors suggested a model in which a deep crustal reservoir is periodically replenished with sublithospheric magma $\left(\operatorname{Iv}_{1}\right.$ subsuite type of magma), and tapped. Fractionation and assimilation of wallrocks leads to subductionlike magmas (e.g. the Tk and Nd suite types of magma; see Figs. 9 and 11). Such a model, referred to as the RTFA model, would explain the alternating non-DUPAL and DUPAL lavas (Fig. 6), which would represent sublithospheric melts and crustal contaminated melts respectively. However, this model is unlikely for several reasons. First, there are no mixing trends between 'uncontaminated' ( $\left.\operatorname{Iv}_{1}\right)$ and 'contaminated' (e.g. Tk and Nd suites) magmas, as would be expected (Fig. 7). Second, it does not explain why the non-DUPAL lavas of the late assemblage bear subduction-like signatures that make them remarkably different in trace element geochemistry from the $\mathrm{Iv}_{1}$ lavas (Fig. 9). Involvement of lithospheric mantle instead of lower crust to explain the subduction-like trace-element patterns would also require mixing trends between 'uncontaminated' and ‘contaminated' melts that are not observed (Fig. 7).

The subduction-like trace element pattern of the low-Ti basalts has usually been considered to be a fingerprint of lithospheric contamination (e.g. Lightfoot et al., 1993; Reichow et al., 2005 for Siberian Traps). Recently, Kieffer et al. (2004) studied the question of lithospheric sources for Oligocene Ethiopian traps, which also contain typical high- and low-Ti basalt series and concluded that "the lithospheric mantle did not contribute significantly to the formation of any of the Oligocene lavas from northern Ethiopia”. This shows that the interpretation of subduction-like trace-element patterns in continental basalts as lithospheric melts is, at least, not unique. Reviewing lithospheric mantle melting literature, Kieffer et al. (2004) posed the question "is the label 'lithosphere' just given to the source of 
any magma whose composition is thought to be inconsistent with that of an asthenosphere or plume source?”.

The timing of volcanism (Fig. 3) can be explained by a starting plume model if dense eclogite patches (for example pieces of subducted oceanic crust) were incorporated into the plume (Lin and van Keken, 2005). However, the plume model is not a unique for explanation for the pulsing volcanism (see below).

\section{Edge-driven convection model}

The edge-driven convection model was suggested by King and Andersen (1998) as an alternative to the plume model. Its basic idea is that at a boundary separating thick cratonic lithosphere and thinner lithosphere upper mantle convective flow may be controlled by the lithospheric structure. Puffer (2001) combined this model with evidence of IAB-like trace element features in Siberian Traps basalts. According to Puffer (2001), lithospheric mantle of the Siberian craton attained subduction-like features (trace elements characteristic of the upper mantle wedge) long before the Permo-Triassic magmatism as a result of paleosubductions. This source, which contained a fusible water-rich mineral assemblage, melted producing voluminous but brief volcanism as a result of redistribution of heat in the upper mantle due to craton-induced convection. However, this model cannot explain the size of the Siberian Traps LIP (Fig. 1) and subduction-like features in the volcanic rocks both on and off the craton (Fig. 11). Neither can it explain the alternating pattern of DUPAL and nonDUPAL basalts in Noril'sk-Kharaelakh subprovince unless the model is coupled with a lithospheric delamination model (see below). It does not resolve the problem of high temperatures for the meimechite melts.

\section{Lithospheric delamination model}

Elkins-Tanton (2005) suggested a model in which a weak plume caused a low degree of partial melting. Melt crystallized within the lithosphere in the form of dense eclogites, and the lithospheric root, subsequently delaminated via a Rayleigh-Taylor instability. After the delamination, deeper sublithospheric material upwelled into the place of the delaminated lithospheric root, and melted to a high degree. Combining this model and the observation of alternating DUPAL and non-DUPAL rocks (Fig. 6), the following scenario can be suggested. The sublithospheric melts are represented by $\mathrm{Iv}_{1}$ subsuite lavas. The delaminated lithospheric 
root is represented by an eclogite layer, which would be stable at about $185 \mathrm{~km}$ depth (Anderson, 2006). After delamination the eclogitic material crossed the solidus and almost completely melted. These melts are represented by the $\mathrm{Iv}_{2}$ and $\mathrm{Iv}_{3}$ subsuites. Sublithospheric material rose and produced non-DUPAL Gd melts. Another portion of the lithospheric eclogite delaminated and again, after crossing the eclogite solidus it melted producing Tk and Nd suite DUPAL basalts. Next, a portion of the sublithospheric material rose to a shallow level where it melted to a high degree producing monotonous non-DUPAL lavas of the late assemblage.

Lithospheric thinning occurred beneath the Tunguska syncline (Fig. 1), which is filled by the most voluminous volcanics (Vasil'ev et al., 2000), in agreement with the delamination model. The number of volcanic pulses (Fig. 3) could be explained as the number of delamination events that occurred in different parts of the Siberian Traps FBP.

However, geochemically similar low-Ti basalts were erupted in different parts of the Siberian Traps FBP (see 'geochemistry’ section). Their similar trace-element compositions require similar mechanisms of origin. Therefore a single weak mantle plume could not have produced the whole FBP via the process of delamination. If several plumes were involved, then this model would inherit all problems of the classical mantle plume model discussed above. In other words, the delamination model requires a cause for the delamination on the scale of the whole Siberian Traps FBP. In addition, it offers no solution for coeval basaltic effusive and acidic intrusive volcanism.

\section{Subduction-related model}

The low-Ti volcanic rock type is the dominant type among the mafic rocks of the Siberian Traps FBP. In the Noril'sk-Kharaelakh subprovince it comprises up to $80 \%$ of the basalts by volume, and in the West Siberian Basin and the Angara-Taseevskaya syncline practically all the rocks belong to this type. In the Maimecha-Kotui subprovince the percentage of the rocks that are low-Ti is the lowest, but they still make up to half of the lava sequence. The important feature of the low-Ti rocks is their IAB-like trace-element patterns (Figs. 9 and 11). Interestingly, the percentage of low-Ti rocks seems to be higher in the southern part and lower in the northern part of the Siberian Traps FBP. If this feature is not an artifact of incomplete sampling then it must correspond to the position of the erupted rocks relative to the paleosubduction systems (Fig. 5); the closer to the subduction system the more prominent IAB-like fingerprint would be expected to be. This geochemical evidence, coupled 
with location of the Siberian Traps FBP in the back-arc tectonic setting (Fig. 5) led to the suggestion that subduction beneath the Siberian part of Pangea and voluminous eruptions of the Siberian Traps FBP are two related phenomena (Ivanov et al., 2004; Ivanov and Balyshev, 2005). A similar conclusion was reached by Zhu et al. (2005) for the Emeishan Traps FBP, which formed in the Late Permian in a similar tectonic setting (Fig. 5). These authors suggested interaction between a lower mantle plume, depleted upper mantle and a recycled subduction component. The question is, however, 'is the lower mantle plume necessary?'. In the case of the Siberian Traps FPB, the lower mantle plume is necessary only to explain the meimechite petrology, which requires too high a temperature for a likely origin in upper mantle plate tectonic processes. However, the meicmechite source could be wet $>1$ wt. \% of water), and if so, a high temperature model is not necessary. This question is thus of particular interest for future investigation.

Ivanov and Balyshev (2005) suggested that the mantle transition zone beneath the Siberian part of Pangea was saturated by water from subduction during the Permian. Dewatering of the transition zone during the latest Permian created a wet upper mantle source, which melted to a high degree. Silver et al. (2006) argued that rapid eruption of voluminous basalts within cratons could be related to tectonic events, which were preceded by relatively long term (> $1 \mathrm{Ma}$ ) supersolidus conditions. They discussed several possible causes of the supersolidus conditions maintained beneath the cratons, one of which is subduction-related increase in volatile components.

This model can explain the large volume of eruptions. For example, in Kamchatka the two most productive volcanoes, neighboring Klyuchevskoi and Tolbachik volcanoes, lie above the edge of a modern subducting slab in an area where lateral flow of normal asthenospheric mantle may influence the hydrated mantle-wedge source (Portnyagin et al., 2005). These volcanoes are characterized by averaged Holocene eruption rates of about 0.02 and $0.01 \mathrm{~km}^{3}$ per year of essentially basaltic magma (Fedotov, 1984). In 1975-1976, the large Tolbachick fissure erupted $2.2 \mathrm{~km}^{3}$ of lava and pyroclastics, comparable to the volume of the largest fissure eruptions in Iceland and Hawaii. The total volume of Holocene volcanic rocks in the vicinity of Tolbachik volcano is about $10^{2} \mathrm{~km}^{3}$ (Fedotov, 1984). The, so-called, zone of the Klyuchevskoi group of volcanoes is about $110 \mathrm{~km}$ long and up to $70 \mathrm{~km}$ wide (Fedotov, 1984). That is not much smaller than the size of the northern subprovinces of the Siberian Traps (e.g. Noril'sk-Kharaelakh 330×110 km, Khantaisk-Rybninsk 250×110 km; Kamensk $\sim 390 \times 110$ km; Kheta $\sim 390 \times 130$ km; Kureika-Letninsk $\sim 330 \times 150$ km; Fig. 2). Extrapolating these values to the size of the whole Siberian Traps FBP easily makes a total 
volume of the order of $4 \times 10^{6} \mathrm{~km}^{3}$ (Table 1). A direct comparison of island arc and Siberian Trap volcanism is not necessary, because of the difference in lithospheric thinning, depth of melting, water recycling style etc.

This model may explain geochemistry of the Siberian Traps FBP and was inspired by the IAB-like geochemistry. Alternating DUPAL and non-DUPAL rocks in the Noril'skKharaelakh subprovince can be explained by recycling of the oceanic crust (eclogites). Patches of eclogite material could be brought to sublithospheric depths by composite diapirs such as those modeled by Yasuda et al. (1998). Eclogite has a much lower solidus than lherzolite and it will melt at high (50-70 \%) degrees of partial melting while lherzolitic ambient rocks remain solid (Anderson, 2005). This could explain the practical absence of mixing between DUPAL and non-DUPAL melts (Fig. 7).

This model probably can explain the eruptions in a several short pulses during the 20$25 \mathrm{Ma}$ of overall duration of the magmatism, and the temporal and spatial coincidence of basaltic and acidic magmatism (granitic batholites are usual in subduction setting). The model does not require uplift as the plume model does. Because the essence of the model is chemical modification of the upper mantle with lowering of its solidus, it does not require thinning of the lithosphere, though pre-existin thinning beneath the Tunguska syncline will increase melt productivity. Primary mica in typical dolerite samples of the Angara-Taseevskaya syncline (Fig. 12) and meimechites of the Maimecha-Kotui subprovince (Fedorenko and Czamanske, 1997), as well as shoshonites in the West Siberian Basin (Medvedev et al., 2003) can be regarded as evidence for water in the source of melting.

Saturation of the transition zone with water is a popular model (Bercovici, Karato, 2003; Ohtani, 2005). The transition zone has a high water capacity due to the high capacity of water of its major minerals; wadsleyite and ringwoodite (Ohtani, 2005). Superhydrous phases can survive under fast subduction conditions in a subducting slab (Litasov and Ohtani, 2003) (Fig. 13). In the anhydrous mineral stability field at depths of 200 to $250 \mathrm{~km}$, the water could be transported by nominally anhydrous minerals such as omphacite, garnet and rutile (Katayama et al., 2006). Due to the metastable mineral assemblage, the subducting slab tends to deflect horizontally while crossing the 410 and $660 \mathrm{~km}$ discontinuities (Bina et al., 2003). Fig. 13 shows that subducting slabs should recharge the transition zone with water throughout geological history. Increasing the amount of water may lead to partial melting within the transition zone (Huang et al., 2005). The mantle transition zone is denser than silicate melt, but in the bottom part of the upper mantle silicate melt is, conversely, denser than ambient peridotitic mantle (Matsukage et al., 2005; Sakamaki et al., 2006). However, increasing the 
amount of water leads to decrease in melt density. Current experimental studies, which have large uncertainties, suggest that the melt will rise from the bottom of the upper mantle due to its own buoyancy at about $6 \mathrm{wt}$. \% of saturation without any additional source of heating. Dense hydrous magnesian silicate E, which is stable at these depths (Fig. 13), contains 11.4 wt. \% of $\mathrm{H}_{2} \mathrm{O}$ (Ohtani, 2005). With conductive heating the phase $\mathrm{E}$ will decompose releasing $\mathrm{H}_{2} \mathrm{O}$ into the silicate melt. Therefore, creating high water concentrations in silicate melts in the bottom part of the upper mantle is not impossible in principle. The process of saturation of the transition zone with water will be inevitably reflected on the Earth's surface as volcanism. Here I suggest that Siberian Traps volcanism and other similar trap volcanism is likely to have been formed by this process.

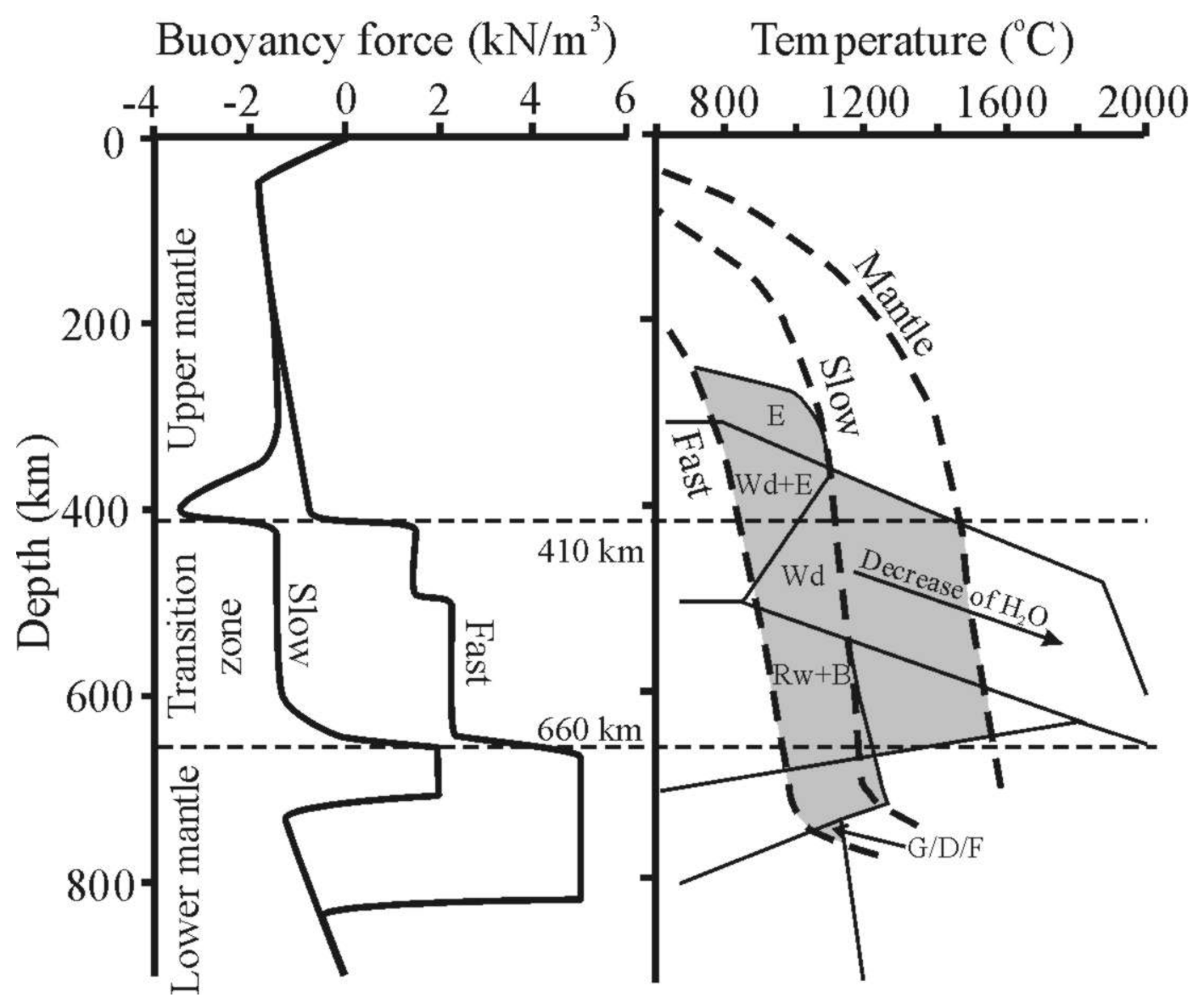

Fig. 13. Saturation of the transition zone with water via subduction. Left panel shows that a fast subducting slab attains positive buoyancy while crossing the $410 \mathrm{~km}$ discontinuity. Both fast and slow subducting slabs attain positive buoyancy while crossing the $660 \mathrm{~km}$ discontinuity (after Bina et al., 2001). Right panel shows stability fields (shadowed) of deep water-bearing minerals in the $\mathrm{CaO}-\mathrm{MgO}-\mathrm{Al}_{2} \mathrm{O}_{3}-\mathrm{SiO}_{2}-\mathrm{H}_{2} \mathrm{O}$ system (after Litasov and Ohtani, 2003). Water-bearing minerals: Wd - wadsleyite, Rw - ringwoodite, $\mathrm{E}$ - dense hydrous magnesian silicate, B and G/D/F - superhydrous phases. Straight lines show boundaries between different mineral assemblages (not included to retain simplicity). 


\section{Subduction-related model and other traps}

Almost 30 years ago, Cox (1978) noted that the Parana, Karoo and Beacon (Ferrar and Kirkpatrick) traps erupted within the southern part of Gondwana in back-arc tectonic settings and because of this coincidence he speculated that their origin was linked to subduction. Other traps, not investigated but mentioned in conjunction with the subduction-related model, were the Deccan Traps, Siberian Traps, North Atlantic Igneous Province and the Columbia River Plateau. The detailed investigation of the Siberian Traps presented here shows that the subduction-related model is viable. The origin of Columbia River Plateau as back-arc phenomenon was considered by Smith (1992). In addition to these examples, the Emeishan traps were considered in relation to subduction by Zhu et al. (2005). All these examples have abundant or dominant low-Ti basalts. The Oligocene Ethiopian province is one of the few examples, which cannot be related directly to subduction. Low-Ti basalts are also abundant there (Kieffer et al., 2004). If all low-Ti basalts originated as a result of hydration of the sublithospheric mantle as suggested here then this implies that dehydration of transition zone may appear not only in areas of near coeval subduction but also in regions of paleosubductions. A relationship between Cenozoic African volcanism and ancient paleosubducted slab was suggested by Balyshev and Ivanov (2001).

\section{CONCLUSIONS}

A number of important pieces of evidence must be explained if the correct origin of the Siberian Traps is to be known:

(1) The Siberian flood basalts erupted in a number of brief volcanic events from the Late Permian until the end of the Middle Triassic. Acidic intrusive magmatism was almost coeval with the basaltic volcanism.

(2) The Siberian Traps erupted within the Pangean supercontinent in a back-arc tectonic setting.

(3) The size and volume of the Siberian Traps flood basalts was about $7 \times 10^{6} \mathrm{~km}^{2}$ and $4 \times 10^{6} \mathrm{~km}^{3}$. Most of the erupted rocks are within the Tunguska syncline. Abundant tuff units correspond to the syncline.

(4) The Tunguska syncline experienced long-term subsidence prior to the initiation of the volcanism. The present-day lithosphere is thinned beneath the same region. 
(5) Low-Ti volcanic rocks with prominent subduction-like trace elements are the dominant type within the Siberian Traps. High-Ti rocks are subordinate. In the Noril'sk area DUPAL and non-DUPAL types of basalts alternate. There is no evidence for mixing between the different rock types.

(6) Petrographic examination of volcanic rocks reveals primary magmatic mica in some samples (though the number of samples with primary water-bearing minerals is not known).

(7) The inferred temperature for meimechite melts in dry (or semi-dry) conditions is too high for the upper mantle and the volatile contents of the source is unknown.

Various models for the origin of the Siberian Traps discussed in literature were tested against the evidence above. The models that fit the observations most poorly seem to be the impact and edge-driven convection models. The plume model can explain the evidence if some predicted evidence have not yet been (or cannot be in principle) observed. The high inferred temperature of the meimechites is the only real supporting evidence. However, the addition of volatiles lowers the temperature of the meimechite primary melts.

The lithospheric delamination model is viable, though it has problems with explaining the size of the Siberian Traps and the causes of the delamination on the scale of the Siberian Traps FBP. It offers no solution for coeval effusive basaltic and intrusive acidic magmatism. It explains the meimechite origin as a volatile-rich source of melting.

A subduction-related model is proposed in this chapter. This model can explain the enormous volume and size of the Siberian Traps, their tectonic setting, coeval basaltic and acidic magmatism, the geochemistry of the dominant low-Ti basalt type and the presence of water-bearing minerals in rocks. This model can explain meimechite origin without a thermal (plume) anomaly by the addition of large quantities of volatiles. The various evidence, coupled with assessment of existing models, enables the conclusion to be drawn that the Siberian Traps phenomenon was related to upper mantle plate tectonics process and not a lower-mantle plume.

\section{ACKNOWLEDGEMENTS}

Gillian R. Foulger motivated me to write this chapter. Linda Elkins-Tanton and Andrew D. Saunders made valuable comments on the manuscript and offered sensible criticism of the subduction-related model. Gillian R. Foulger and Donna M. Jurdy provided helpful editorial support. Viktor V. Rybov and Artem Y. Shevko helped with locating samples 
provided by Russian geologists for the ${ }^{40} \mathrm{Ar} /{ }^{39} \mathrm{Ar}$ study of Renne and Basu (1991). The work was supported by RFBR projects (05-05-64477 and 05-05-64281) and the Russian Science Support Foundation.

\section{REFERENCES}

Al'mukhamedov, A.I., Medvedev, A.Ya., and Zolotukhin, V.V., 2004, Chemical Evolution of the Permian-Triassic Basalts of the Siberian Platform in Space and Time: Petrology, v. 12, p. 297-311.

Alvarez, L.W., Alwarez, W., Asaro, F., and Michel, H.V., 1980, Extraterrestrial cause for the Cretaceous-Tertiary extinction: Science, v. 208, p. 1095-1108.

Anderson, D.L., 2001, Top-down tectonics: Science, v. 293, p. 216-218.

Anderson, D.L., 2005, Large igneous provinces, delamination, and fertile mantle: Elements, v. 1, p. 271-275.

Anderson, D.L., 2006, Speculations on the nature and cause of mantle heterogeneity: Tectonophysics, v. 416, p. 7-22.

Arndt, N., Lehnert, K., and Vasil'ev, Y., 1995, Meimechites: highly magnesian, contaminated alkaline magmas from the subcontinental lithosphere: Lithos, v. 34, p. 41-59.

Baksi, A.K., and Farrar, E., 1991, ${ }^{40} \mathrm{Ar} /{ }^{39} \mathrm{Ar}$ dating of the Siberian Traps, USSR: Evaluation of the ages of the two major extinction events relative to episodes of flood-basalt volcanism in USS and the Deccan Traps, India: Geology, v. 19, p. 461-464.

Balyshev, S.O. and Ivanov, A.V., 2001. Low-density anomalies in the mantle: ascending plumes and/or heated fossil lithospheric plates: Doklady Earth Sciences, v. 380, p. 858-862.

Basu, A.R., Poreda, R.J., Renne, P.R., Teichmann, F., Vasiliev, Yu.R. Sobolev, N.V., and Turrin, B.D., 1995, High- ${ }^{3}$ He plume origin and temporal-spatial evolution of the Siberian flood basalts: Science, v. 269, p. 822-825.

Bercovici, D., and Karato, S.-I., 2003, Whole-mantle convection and the transitionzone water filter: Nature, v. 425, p. 39-44.

Bina, C.R., Stein, S., Marton, F.C., and Van Ark, E.M., 2001, Implications for slab mineralogy for subduction dynamics, Physics of Earth and Planetary Interiors, v. 127, p. 5166. 
Bowring, S.A., Erwin, D.H., Jin, Y.G., Martin, M.W., Davidek, K. and Wang, W., 1998. U/Pb zircon geochronology of the end-Permian mass extinction. Science, 280, 10391045.

Burke, K., and Torsvik, T.H., 2004, Derivation of large igneous provinces of the past 200 million years from long-term heterogeneities in the deep mantle: Earth and Planetary Science Letters, v. 227, p. 531-538.

Burov, E., and Guillou-Frottier, L., 2005, The plume head-continental lithosphere interaction using a tectonically realistic formulation for the lithosphere: Geophysical Journal International, v. 161, p. 469-490.

Campbell, I.H., 2005, Large igneous provinces and the mantle plume hypothesis: Elements, v. 1, p. 265-270.

Campbell, I.H., and Griffiths, R.W., 1990, Implications of mantle plume structure for the evolution of flood basalts: Earth and Planetary Science Letters, v. 99, p. 79-93.

Chernysheva E.A., Kharin G.S., and Stolbov, N.M., 2005, Basaltic magmatism in Arctic seas related to the Mesozoic activity of the Iceland plume: Petrology, v. 13, p. 289-304.

Czamanske, G.K., Gurevich, A.B., Fedorenko, V., and Simonov, O., 1998, Demise of the Siberian plume: paleogeographic and paleotectonic reconstruction from the prevolcanic and volcanic records, North-Central Siberia: International Geology Review, v. 40, p. 95-115.

Dalrymple, G.B., Czamanske, G.K., Fedorenko, V.A., Simonov, O.N., Lanphere, M.A., and Likhachev, A.P., 1995, A reconnaissance ${ }^{40} \mathrm{Ar} /{ }^{39} \mathrm{Ar}$ study of ore-bearing and related rocks, Siberian Russia: Geochimica et Cosmochimica Acta, v. 59, p. 2071-2083.

Dmitriev, Yu.I., 1973, Mesozoic trap volcanism in the centre and periphery of the Tunguska syncline: Izvestiya AN USSR, Geological series, No 10, p. 58-67. (in Russian)

Dobretsov, N.L., 2003, Mantle plumes and their role in the formation of anorogenic granitoids, Geologiya i geofizika, v. 44, p. 1243-1261.

Dobretsov, N.L., 2005, Large igneous provinces of Asia (250 Ma): Siberian and Emeishan traps (plateau basalts) and associated granitoids: Geologiya i geofizika, v. 46, p. 870-890.

Dobretsov, N.L., Vladimirov, A.G., and Kruk, N.N., 2005, Permo-Triassic magmatism in the Altai-Sayan fold system as a reflection of the Siberian superplume, Doklady Earth Sci. v. 400 , p. $40-43$.

Dorendorf, F., Wiechert, U., and Wörner, G., 2000, Hydrated sub-arc mantle: a source for the Klyuchevskoy volcano, Kamchatka/Russia: Earth and Planetary Science Letters, v. 175, p. 69-86. 
Dun, T. and Sen, C., 1994, Mineral/matrix partition coefficients for orthopyroxene, plagioclase, and olivine in basaltic to andesitic systems: A combined analytical and experimental study: Geochim. Cosmochim. Acta., v. 58, p. 717-733.

Dupré, H.B., and Allègre, C.J., 1985, Pb-Sr-Nd isotope data of Indian ocean ridges: New evidence of large-scale mapping of mantle heterogeneities: Earth and Planetary Science Letters, v. 76, p. 288-298.

Egorkin, A.V., 2001, Upper mantle structure below the Daldyn-Alakitsk kimberlite field by nuclear explosion seismograms: Geology of Ore Deposits, v. 43, p. 19-32.

Egorkin, A.V., 2004, Mantle structure of the Siberian platform: Izvestiya-Physics of the Solid Earth, v. 40, p. 385-394.

Elkins-Tanton, L.T., 2005, Continental magmatism caused by lithospheric delamination, in Foulger, G.R., Natland, J.H., Presnall, D.C., and Anderson, D.L., Plates, plumes and paradigms: Geological Society of America Special Paper 388, p. 449-462.

Elkins-Tanton, L.T., Draper, D.S., Agee, C.B., Jewell, J., Thorpe, A., and Hess, P.S, submitted, The last lavas of the Siberian flood basalts: results from experimental petrology: Contributions to Mineralogy and Petrology.

Erwin, D.H., Bowring, S.A., and Yugan, J., 2002. End-Permian mass extinctions: A review, in Koeberl, C., and MacLeod, K.G., Catastrophic Events and Mass Extinctions: Impacts and Beyond: Boulder: Geological Society of America Special Paper 356, p. 363-383.

Escrig, S., Capmas, F., Dupré, B., and Allègre, C.J., 2004, Osmium isotopic constraints on the nature of the DUPAL anomaly from Indian mid-oceanic-ridge-basalts, Nature, v. 431, p. 59-63.

Fedorenko, V.A., 1981, Petrochemical series of effusive rocks in Noril'sk region: Geologiya i Geofizika, No 6, p. 77-88. (in Russian)

Fedorenko, V.I., Lightfoot, P.C., Naldrett, A.J., Czamanske, G.K., Hawkesworth, C.J., Wooden, J.L., and Ebel, D.S., 1996. Petrogenesis of the flood-basalt sequence at Noril'sk, North Central Siberia, International Geology Review, v. 38, p. 99-135.

Fedoseev, G.S., Sotnikov, V.I., and Rikhvanov, L.P., 2005, Geochemistry and geochronology of Permo-Triassic basites in the northwestern Altai-Sayan folded area: Geologiya i geofizika, v. 46, p. 289-302.

Fedotov, S.A., Editor-in-Chief, 1984, Large Tolbachik fissure eruption. Kamchatka 1975-1976: Moscow, Nauka. (In Russian).

Feoktistov, G.D., 1979. Petrology and conditions for formation of trap sills. Nauka, Novosibirsk (in Russian) 
Gilkson, A.Y., 1999, Oceanic mega-impacts and crustal evolution: Geology, v. 27, p. 387-390.

Green, T.H., 1994, Experimental studies of trace-element partitioning applicable to igneous petrogenesis: Sedona 16 years later: Chemical Geology, v. 117, p. 1-36.

Hart, S., 1984, A large-scale isotope anomaly in the Southern Hemisphere mantle: Nature, v. 309, p. 753-757.

Hagstrum, J.T., 2005, Antipodal hotspots and bipolar catastrophes: Were large oceanic large-body impacts the cause?: Earth and Planetary Science Letters, v. 236, p. 13-27.

Hart, S.R., and Dun, T., 1993, Experimental cpx/melt partitioning of 24 trace elements: Contrib. Mineral. Petrol., v. 113, p. 1-8.

He, B., Xu, Y.-G., Chung, S.-L., Xiao, L., and Wang, Y., 2003, Sedimentary evidence for a rapid kilometer-scale crustal doming prior to the eruption of the Emeishan flood basalts: Earth and Planetary Science Letters, v. 213, p. 391-405.

Horan, M.F., Walker, R.J., Fedorenko, V.A., and Czamanske, G.K., 1995, Osmium and neodymium isotopic constraints on the temporal and spatial evolution of the Siberian flood basalt sources: Geochimica et Cosmochimica Acta, v. 59, p. 5159-5168.

Huang, X.G., Xu, Y.S., and Karato, S.I., 2005, Water content in the transition zone from electrical conductivity of wadsleyite and ringwoodite: Nature, v. 434, p. 746-749.

Hyndman, R.D., Currie, C.A., and Mazzotti, S.P., 2005, Subduction zone backarcs, mobile belts, and orogenic heat: GSA Today, v. 15, p. 4-11.

Ivanov, A.V., 2006, Systematic difference between U-Pb and ${ }^{40} \mathrm{Ar} /{ }^{39} \mathrm{Ar}$ dates: reason and way for accounting for: Geochemistry International, No 10 (in press)

Ivanov, A.V., and Balyshev, S.V., 2005, Mass flux across the lower-upper mantle boundary: vigorous, absent, or limited? in Foulger, G.R., Natland, J.H., Presnall, D.C., and Anderson, D.L., Plates, plumes and paradigms: Geological Society of America Special Paper 388, p. 327-346.

Ivanov, A.V., Demonterova, E.I., Rasskazov, S.V., Yasnygina, T.A., and Feoktistov, G.D., submitted, Low-Ti melts from the Southeastern Siberian Traps Large Igneous Province: Evidence for a water-rich mantle source?: Lithos.

Ivanov, A.V., Rasskazov, S.V., Demonterova, E.I., Yasnygina, T.A., Maslovskaya, M.N., and Feoktistov, G.D., 2004, Why Low-Ti Basalts of the Siberian Traps Large Igneous Province are Similar to Island Arc Basalts? in AGU Fall meeting, section V16. 
Ivanov, A.V., Rasskazov, S.V., Feoktistov, G.D., He, H., and Boven, A., 2005, ${ }^{40} \mathrm{Ar} /{ }^{39} \mathrm{Ar}$ dating of Usol'skii sill in the southeastern Siberian Traps Large Igneous Province: evidence for long-lived magmatism, Terra Nova, v. 17, p. 203-208.

Ivanov, A.V., Ryabov, V.V., Shevko, A.Y., and He., H., 2006, Single short episode or multiple non-coeval episodes of voluminous basaltic volcanism of the Siberian Traps?: data of ${ }^{40} \mathrm{Ar} /{ }^{39} \mathrm{Ar}$ dating. in: Proceedings of III Russian conference on isotopic geochronology, Moscow, IGEM RAS, p. 278-282. (in Russian).

Ivanov, B.A., and Melosh, H.J., 2003, Impacts do not initiate volcanic eruptions: Eruptions close to the crater: Geology, v. 31, p. 869-872.

Jones, A.P., Price, G.D., Price, N.J., DeCarli, P.S., and Clegg, R., 2002, Impact induced melting and the development of large igneous provinces: Earth and Planetary Science Letters, v. 202, p. 551-561.

Jones, A.P., Wünemann, K., and Price, G.D., 2005, Modeling impact volcanism as a possible origin for the Ontong Java Plateau, in Foulger, G.R., Natland, J.H., Presnall, D.C., and Anderson, D.L., Plates, plumes and paradigms: Geological Society of America Special Paper 388, p. 711-720.

Kamo, S.L., Czamanske, G.K., and Krogh, T.E., 1996, A minimum U-Pb age for Siberian flood-basalt volcanism, Geochimica et Cosmochimica Acta, v. 60, p. 3505-3511.

Kamo, S.L., Czamanske, G.K., Amelin, Yu., Fedorenko, V.A., Davis, D.W., and Trofimov, V.R., 2003, Rapid eruption of Siberian flood-volcanic rocks and evidence for coincidence with the Permian-Triassic boundary and mass extinction at 251 Ma: Earth and Planetary Science Letters, v. 214, p. 75-91.

Katayama, I., Nakashima, S. and Yurimoto, H., 2006, Water content in natural eclogite and implication for water transport into the deep upper mantle: Lithos, v. 86, p. 245259.

Kazanskii, A.Yu., Kazanskii, Yu.P., Saraev, S.V., and Moskvin, V.I., 2000, The Permo-Triassic boundary in volcanosedimentary section of the West-Siberian plate according to paleomagnetic data (from studies of the core from the Tyumenskaya superdeep borehole SD-6): Geologiya i Geofizika, v. 41, p. 327-339.

Kelemen, P.B., Joyce, D.B., Webster, J.D. and Holloway, J.R., 1990, Reaction between ultramafic wall rock and fractionating basaltic magma: Part II, Experimental investigation of reaction between olivine tholeiite and harzburgite at 1150 and $1050^{\circ} \mathrm{C}$ and 5 kbar: J. Petrol., v. 31, p. 99-134. 
Kieffer, B., Arndt, N., Lapierre, H., Bastien, F., Bosch, D., Pecher, A., Yirgu, G., Ayalew, D., Weis, D., Jerram, D.A., Keller, F., and Meugniot, C., 2004, Flood and shield basalts from Ethiopia: Magmas from the African superswell: Journal of Petrology, v. 45, p. 793-834.

King, S.D., and Anderson, D.L., 1998, Edge-driven convection: Earth and Planetary Science Letters, v. 160, p. 289-296.

Koeberl, C., Gilmour, L., Reimold, W.U., Claeys, P., and Ivanov, B., 2002, EndPermian catastrophe by bolide impact: Evidence of a gigantic release of sulfur from the mantle: Comment: Geology, v. 30, p. 855-856.

Kogarko, L.N., and Ryabchikov, I.D., 1995, Conditiona of meimechite magmas formation (Polar Siberia) based on the geochemical data, Geokhimia, v. 12, p. 1699-1709.

Korenaga, J., 2005, Why did not the Ontong Java Plateau form subaerially?: Earth and Planetary Science Letters, v. 234, p. 385-399.

Le Bas, M.J., and Streckeisen, A.L., 1991, The UIGS systematics of igneous rocks: Journal of Geological Society, London, v. 148, p. 825-833.

Lightfoot, P.C., Hawkesworth, C.J., Hergt, J., Naldrett, A.J., Gorbachev, N.S., Fedorenko, V.A., and Doherty, W., 1993, Remobilisation of the continental lithosphere by a mantle plume: major-, trace-element, and Sr-, Nf-, and Pb-isotope evidence from picritic and tholeitic lavas of the Noril'sk District, Siberian Trap, Russia: Contributions to Mineralalogy and Petrology, v. 114, p. 171-188.

Lin, S.C. and van Keken, P.E., 2005, Multiple volcanic episodes of flood basalts caused by thermochemical mantle plumes: Nature, v. 436, p. 250-252.

Litasov, K., and Ohtani, E., 2003, Stability of various hydrous phases in CMAS pyrolite- $\mathrm{H}_{2} \mathrm{O}$ system up to $25 \mathrm{GPa}$ : Physics and Chemistry of Minerals, v. 30, p. 147-156.

Lysak, S.V., 1984, Terrestrial heat flow in the south of East Siberia: Tectonophysics, v. 103, p. 205-215.

Malitch, N.S., Editor-in-Chief., 1999, Geological map of Siberian platform and adjoining areas. Scale 1:1500000. St-Petersburg, VSEGEI.

Masaitis, V.L., 1983, Permian and Triassic volcanism of Siberia: Zapiski Vserossiiskogo Mineralogicheskogo Obshestva, No 4, p. 412-425. (In Russian)

Matsukage, K.N., Jing, Z.C., and Karato, S., 2005, Density of hydrous silicate melt at the conditions of Earth's deep upper mantle: Nature, v. 438, p. 488-491.

McDonough, W.F., and Sun, S.-S., 1995, The composition of the Earth: Chemical Geology, v. 120, p. 223-253. 
Medvedev, A.Ya., Al'mukhamedov, A.I., and Kirda, N.P., 2003, Geochemistry of Permo-Triassic volcanic rocks of West Siberia: Geologiya i Geofizika, v. 44, p. 86-100.

Meyzen, C.M., Ludden, J.N., Humler, E., Luais, B., Toplis, M.J., Mevel, C., and Storey, M., 2005, New insights into the origin and distribution of the DUPAL isotope anomaly in the Indian Ocean mantle from MORB of the Southwest Indian Ridge: Geochemistry, Geophysics, Geosystems, v. 6, Q11K11.

Milanovskiy, Y.Y., 1976, Rift zones of the geologic past and their associated formations. Report 2: International Geology Review, v. 18, p. 619-639.

Min, K., Mundil, R., Renne, P.R. and Ludwig, K.R., 2000. A test for systematic errors in ${ }^{40} \mathrm{Ar} /{ }^{39} \mathrm{Ar}$ geochronology through comparison with $\mathrm{U} / \mathrm{Pb}$ analysis of a 1.1-Ga rhyolite. Geochem. Cosmochem. Acta. 64, 73-98.

Morgan, W.J., 1971, Convection plumes in the lower mantle: Nature, v. 230, p. 42-43.

Morozov, I.B., Morozova, E.A., Smithson, S.B., Solodilov, L., 1999, Heterogeneity of the uppermost mantle beneath Russian Eurasia from the ultralong-range profile Quartz: J. Geophys. Res., v. 104, p. 20329-20348.

Mundil, R., Ludwig, K.R., Metcalfe, I. and Renne, P.R., 2004. Age and timing of the Permian Mass Extinctions: U/Pb dating of closed-system zircons. Science, 305, 1760-1763.

Naldrett, A.J., Lightfoot, P.C., Fedorenko, F.A., Gorbachev, N.S., and Doherty, W., 1992, Geology and geochemistry of intrusions and flood basalts of the Noril'sk region, USSR with implications for the origin of the Ni-Cu ores: Economic Geology, v. 87, p. 975-1004.

Nikishin, A.M., Ziegler, P.A., Abbott, D., Brunet, M.-F., and Cloetingh, S., 2002, Permo-Triassic intraplate magmatism and rifting in Eurasia: implications for mantle plumes and mantle dynamics: Tectonophysics, v. 351, p. 3-39.

Ohtani, E., 2005, Water in the mantle: Elements, v. 1(1), p. 25-30.

Pavlenkova, N.I., 2006, Long-Range profile data on the upper-mantle structure in the Siberian platform: Russian Geology and Geophysics, v. 47, p. 626-641.

Pavlenkova, G.A., and Pavlenkova, N.I., 2006, Upper mantle structure of the Northern Eurasia from peaceful nuclear explosion data: Tectonophysics, v. 416, p. 33-52.

Pavlenkova G.A., Priestley K., Cipar J. 2002, 2D model of the crust and uppermost mantle along rift profile, Siberian craton: Tectonophysics, v. 355, p. 171-186.

Podurushin, V.F., 2002, Geodynamics of the West-Siberian platform and its margins: Izvestiya Vyshikh Uchebnykh Zavedeniy. Geologiya I Razvedka, No 1, p. 30-37. (in Russian). 
Pontevivo, A., and Thybo, H., 2006, Test of the upper mantle low velocity layer in Siberia with surface waves: Tectonophysics, v. 416, p. 113-131.

Portnyagin, M., Hoernle, K., Avdeiko, G., Hauff, F., Werner, R., Bindeman, I., Uspensky, V., and Garbe-Schönberg, D., 2005, Transition from arc to oceanic magmatism at the Kamchatka-Aleutian junction: Geology, v. 33, p. 25-28.

Puffer, J.H., 2001, Contrasting high filed strength element content of continental flood basalts from plume versus reactivated-arc sources: Geology, v. 29, p. 675-678.

Reichow, M.K., Saunders, A.D., White, R.V., Pringle, M.S., Al'mukhamedov, A.I., Medvedev, A.I., and Kirda, N.P., 2002, ${ }^{40} \mathrm{Ar} /{ }^{39} \mathrm{Ar}$ dates from the West Siberian Basin: Siberian flood basalt province doubled: Science, v. 296, p. 1846-1849.

Reichow, M.K., Saunders, A.D., White, R.V., Al'mukhamedov, A.I., and Medvedev, A.Ya., 2005, Geochemistry and petrogenesis ob basalts from the West Siberian Basin: an extension of the Permo-Triassic Traps, Russia: Lithos, v. 79, p. 425-452.

Renne, P.R., 1995, Excess ${ }^{40} \mathrm{Ar}$ in biotite and hornblende from the Norilsk 1 intrusion, Siberia: implication for the age of Siberian Traps: Earth and Planetary Science Letters, v. 131, p. $165-176$.

Renne, P.R., and Basu, A.R., 1991, Rapid eruption of the Siberian Traps flood basalts at the Permo-Triassic boundary: Science, v. 253, p. 176-179.

Renne, P.R., Zichao, Z., Richards, M.A., Black, M.T., Basu, A.R., 1995, Synchrony and casual relations between Permian-Triassic boundary crises and Siberian flood volcanism: Science, v. 269, p. 1413-1416.

Renne, P.R., Swisher, C.C., Deino, A.L., Karner, D.B., Owens, T.L., and DePaolo, D.J., 1998, Intercalibration of standards, absolute ages and uncertainties in ${ }^{40} \mathrm{Ar} /{ }^{39} \mathrm{Ar}$ dating: Chemical Geology, v. 145, p. 117-152.

Sakamaki, T., Suzuki, A. and Ohtani, E., 2006, Stability of hydrous melt at the base of the Earth’s upper mantle: Nature, v. 439, p. 192-194.

Saunders, A.D., England, R.W., Reichow, M.K., and White, R.V., 2005, A mantle plume origin for the Siberian traps: uplift and extension in the West Siberian Basin, Russia: Lithos, v. 79, p. 407-424.

Shaw, D.M., 1970, Trace element fractionation during anatexis: Geochim. Cosmochim. Acta., v. 34, p. 237-243.

Silver, P.G., Behn, M.D., Kelley, K., Schmitz, M., and Savage, B., 2006, Understanding cratonic flood basalts: Earth Planet. Sci. Lett., v. 245, p. 190-201. 
Smith, A.D., 1992, Back-Arc convection model for Columbia River basalt genesis: Tectonophysics, v. 207, p. 269-285.

Sobolev, A.V., Kamenetsky, V.S., and Kononkova, N.N., 1991, New data on petrology of meymechites: Geochimiya, No 8, p. 1084-1095.

Spell, T.L., and McDougall, I., 2003, Characterization and calibration of ${ }^{40} \mathrm{Ar} /{ }^{39} \mathrm{Ar}$ dating standards: Chemical Geology, v. 198, p. 189-211.

Sun, S.-S., and McDonough, W.F., 1989, Chemical and isotopic systematics of oceanic basalts: Implications for mantle composition and process, in Sounders, A.D., and Norry, M.J., Magmatism in the oceanic basins: Geological Society London Special Publication 42, p. 313-345.

Thybo, H. and Perchuc, E., 1997, The seismic $8^{\circ}$ discontinuity and partial melting in continental mantle: Science, v. 275, p. 1626-1629.

Vasil'ev, Yu.R., Zolotukhin, V.V., Feoktistov, G.D., and Prusskaya, S.N., 2000, Evaluation of the volumes and genesis of Permo-Triassic Trap magmatism of the Siberian Platform: Geologiya i Geofizika, v. 41, p. 1696-1705. (In Russian).

Venkatesan, T.R., Kumar, A., Gopalan, K., Al’mukhamedov, A.I., 1997, ${ }^{40} \mathrm{Ar}-{ }^{39} \mathrm{Ar}$ age of Siberian basaltic volcanism: Chemical Geology, v. 138, p. 303-310.

Vernikovsky, V.A., Pease, V.L., Vernikovskaya, A.E., Romanov, A.P., Gee, D.G., and Travin, A.V., 2003, First report of early Triassic A-type granite and syenite intrusions from Taimyr: product of the northern Eurasian superplume?: Lithos, v. 66, p. 23-36.

Vinogradov, A.P., Editor-in-chief., 1968, The lithologo-paleogeographic maps of USSR. Volume II: Ministry of geology of the USSR \& USSR Academy of Sciences.

Vladimirov, A.G., Kozlov, M.S., Shokal’skii, S.P., Khalilov, V.A., Rudnev, S.N., Kruk, N.N., Vystavnoi, S.A., Borisov, S.M., Berezhikov, Y.K., Metsner, A.N., Babin, G.A., Mamlin, A.N., Murzin, O.M., Nazarov, G.V., and Makarov, V.A., 2001, Major epochs of the intrusive magmatism of Kuznetsk Alatau, Altai, and Kalba (from U-Pb isotope dates): Geologiya i Geofizika, v. 42, p. 1157-1178.

Vrublevskii, V.V., Gertner, I.F., Polyakov, G.V., Izokh, A.E., Krupchatnikov, V.I., Travin, A.V., and Voitenko, N.N., 2004, Ar-Ar isotopic age of lamproite dikes of the Chua complex, Gornyi Altai: Doklady Earth Science, v. 399A, p. 1252-1255.

Walderhaug, H.J., Eide, E.A., Scott, R.A., Inger, S., and Golionko, E.G., 2005, Paleomagnetism and ${ }^{40} \mathrm{Ar} /{ }^{39} \mathrm{Ar}$ geochronology from the South Taimyr igneous complex, Arctiv Russia: a Middle-Late Triassic magmatic pulse after Siberian flood-basalt volcanism: Geophysical Journal International, v. 163, p. 501-517. 
Wooden, J.L., Czamanske, G.K., Fedorenlo, V.A., Arndt, N.T., Chauvel, C., Bouse, R.M., King, B-S.W., Knight, R.J., and Siems, D.F., 1993, Isotopic and trace-element constraints on mantle and crustal contributions to characterization of Siberian continental flood basalts, Noril’sk area, Siberia: Geochimica et Cosmochimica Acta, v. 57, p. 3677-3704.

Yarmolyuk, V.V., Litvinovsky, B.A., Kovalenko, V.I., Jahn, B.M., Zanvilevich, A.N., Vorontsov, A.A., Zhuravlev, D.Z., Posokhov, V.F., Kuz'min, D.V., and Sandimirova G.P., 2001, Formation stages and sources of the peralkaline granitoid magmatism of the Northern Mongolia-Transbaikalia rift belt during the Permian and Triassic: Petrology, v. 9, p. 302-328.

Yasuda, A., and Fujii, T., 1998, Ascending subducted oceanic crust entrained within mantle plumes: Geophysical Research Letters, v. 25, p. 1561-1564.

Zack, T., Foley, S.F. and Jenner, G.A., 1997, A consistent partitioning coefficient set for clinopyroxene, amphibole and garnet from laser ablation microprobe analyses of garnet pyroxenite from Kakanui, New Zealand: Nes Jb. Miner. Abh., v. 172, p. 23-41.

Zhu, B.-G., Hu, Y.-G., Chang, X.-Y., Xie, J., and Zhang, Z.-W., 2005, The Emeishan large igneous province originated from magmatism of a primitive mantle plus subducted slab: Russian Geology and Geophysics, v. 46, p. 904-921.

Zolotuhin, V.V., Vilenskii, A.M., Vasil'ev, Yu.P., Mezhvilk, A.A., Ryabov, V.V., and Shcherbakova, Z.V., 1984, Magnesium basic rocks of the western Siberian platform and questions of nickel-bearing. Novosibirsk, Nauka. (in Russian)

Zolotukhin, V.V., Vilenskii, A.M., and Dyuzhikov, O.A., 1986, Basalts of Siberian platform. Novosibirsk, Nauka. (in Russian)

Zonenshain, L.P., Kuzmin, M.I., and Natapov, L.M., 1990. Geology of the USSR: plate tectonic synthesis: American Geophysical Union Geodynamic Series 21.

Zorin, Y.A., 1999, Geodynamics of the western part of the Mongolia-Okhotsk collisional belt, Trans-Baikal region (Russia) and Mongolia, Tectonophysics, v. 306, p. 33-56.

Zorin, Yu.A., Belichenko, V.G., Turutanov, E.K., Kozhevnikov, V.M., Sklyarov, E.V., Tomurtogoo, O., Khosbayar, P., Arvisbaatar, N., and Biambaa, C., 1998, Terranes of East Mongolia and Central Trans-Baikal region and evolution of the Mongolia-Okhotsk fold belt: Geologiya i Geofizika, v. 39, p. 11-25.

Zorin, Yu.A., Mordvinova, V.V., Turutanov, E.Kh., Belichenko, V.G., Artemyev, A.A., Kosarev, G.L., and Gao, S.S. (2002) Low seismic velocity layers in the Earth's crust beneath Eastern Siberia (Russia) and Central Mongolia: receiver function data and their possible geological interpretation: Tectonophysics, v. 359, p. 307-327. 
Zorin, Yu.A., and Vladimirov, B.M., 1989, On the genesis of trap magmatism of the Siberian platform: Earth and Planetary Science Letters, v. 93, p. 109-112. 